\title{
THE JOINT-DECISION TRAP: LESSONS FROM GERMAN FEDERALISM AND EUROPEAN INTEGRATION
}

\author{
FRITZ W. SCHARPF
}

Compared to early expectations, the process of European integration has resulted in a paradox: frustration without disintegration and resilience without progress. The article attempts to develop an institutional explanation for this paradox by exploring the similarities between joint decision making ('Politikverflechtung') in German federalism and decision making in the European Community. In both cases, it is argued, the fact that member governments are directly participating in central decisions, and that there is a de facto requirement of unanimous decisions, will systematically generate sub-optimal policy outcomes unless a 'problem-solving' (as opposed to a 'bargaining') style of decision making can be maintained. In fact, the 'bargaining' style has prevailed in both cases. The resulting pathologies of public policy have, however, not resulted either in successful strategies for the further Europeanization of policy responsibilities or in the disintegration of unsatisfactory joint-decision systems. This 'joint-decision trap' is explained by reference to the utility functions of member governments for whom present institutional arrangements, in spite of their sub-optimal policy output, seem to represent 'local optima' when compared to either greater centralization or disintegration.

\section{INTRODUCTION}

In political philosophy government is justified, in comparison to anarchy, as an arrangement for improving the chances of purposive fate control through the collective achievement of goals (including protection against threats) which would be beyond the reach of individual action. The same logic of effectiveness would justify enlarging the scale of government whenever the achievement of goals, or the defence against threats, would be aided by the larger action space and resources of larger units. The countervailing logic of democratic legitimacy, however, would favour smaller units of government in which a greater homogeneity of preferences would allow collective choices to approximate aggregate individual choices. It is also

Fritz W. Scharpf is Director at the Max-Planck-Institut für Gesellschaftsforschung, Cologne. Manuscript completed in 1988. Shorter versions (1986) have appeared under the title Die Politikverflechtungsfalle: Europäische Integration und deutscher Föderalismus im Vergleich' in: Politische Vierteljahresschrift 26: 323-56 (Dezember 1985) and under the title ' $\mathrm{La}$ trapolla della decisione congiunta: federalismo tedesco e integrazione europea' in Stato e Mercato 17: 175-216 (Agosto 1986).

Public Administration Vol. 66 Autumn 1988 (239-278)

(C) 1988 Royal Institute of Public Administration ISSN 0033-3298 \$3.00 
claimed that a world of small government units would not, in the first place, produce most of the threats to security that large units of government are needed to provide protection against (Kohr 1978).

The search for the optimal scale of government, in the light of apparent tradeoffs between the greater effectiveness of larger and the greater legitimacy of smaller units, is the subject of sophisticated speculation in the fields of public choice, fiscal federalism and political science (Breton and Scott 1978; Kirsch 1977; Mueller 1979; Oates 1972; Olson 1969; E. Ostrom 1984; Rothenberg 1970; Tullock 1969; Ylvisaker 1959). Historically, of course, it was the nation state which, during the nineteenth and early twentieth centuries, seemed to provide the most attractive balance: sufficiently large and resource-rich to cope with most external threats, it was also internally homogeneous enough to facilitate the acceptance of collective choices. Indeed, the history of national unification in the nineteenth century, as well as of the disintegration of multi-national empires in the twentieth century, suggest that national 'identity' was a more powerful determinant of the prevailing scale of government authority than either the greater internal homogeneity of subnational communities or the greater power resources of supra-national political units (Sharpe 1985).

In the post-1945 period, however, political authority on the scale of the nation state seemed to have lost much of its claim to optimality. Having been rescued from military disaster by the United States for the second time, most European nation states chose to renounce their claims to military self-sufficiency in favour of an American-led alliance. At the same time, European recovery, not only from war damages but also from the pre-war disintegration of the international economy, seemed to require the creation of a larger 'common market' at least within Western Europe. For the committed 'Europeanists', of course, this was only a beginning. They hoped, and worked, for a politically united Western Europe which would again be able to hold its own in a world dominated by military and economic 'super powers'. In these hopes they were encouraged by integration theories in the social sciences, expecting closer communications among member countries, and the 'forward spill overs' of functionally specific European institutions, to generate the political momentum for an ever deeper and wider social and political integration (Deutsch 1957; Haas 1958). Thus, NATO and the EEC were seen as only the first steps on the road to 'a more complete union' modelled after the federal system of the United States of America.

Thirty years later, NATO is still no more than a defence alliance under the undisputed hegemony of the United States, but as such it has been remarkably successful by its own standards. The European Community, on the other hand, has increased its territorial scale from the original six to twelve member states, and it has also broadened its functional responsibilities beyond the specific mandates of the original treaty. Indeed, there is considerable pressure for further functional expansion in such areas as industrial policy, technology policy, communications policy and monetary policy, where the Community is urged to assume governing responsibilities for which the nation state has become too small.

Nevertheless it is fair to say that the Community, unlike NATO, is not characterized 
by the self-satisfaction of secure accomplishments but, rather, by a pervasive sense of disappointment, frustration and general malaise. The 'Common Market', to be sure, is functioning more or less effectively as a customs union in the industrial sector, constraining the protectionist tendencies of member countries in exchange for the growing protectionism of the Community itself. In industrial policy, however, the relative success of common ventures in aerospace resulted mainly from collaboration outside of Community institutions, while Community efforts to cushion the decline of old industries are severely criticized as economically inefficient. Some beneficial programmes, such as the Regional Fund and the Social Fund, are ridiculously under-financed in relation to the problems they are supposed to attack, while in other areas the transfer of regulatory powers to the European level has mainly had the effect of frustrating more aggressive initiatives for pollution control or consumer protection at the national level. Most important, however, the centrepiece of European economic integration, Common Agricultural Policy, is now almost universally considered a grandiose failure. CAP has managed to generate huge agricultural surpluses, at the expense of European consumers and taxpayers who have to pay twice, for food prices far above the world-market level as well as for enormous subsidies for the purchase, storage and disposal of surplus production. And in spite of it all, CAP has neither been able to assure acceptable family incomes for small European peasants, nor has it maintained its major original achievement of common prices in a common European market for agricultural goods.

Thus, if there should be any 'spill overs' at all from functional integration, they are more likely to be negative. Indeed, the controversies over British contributions, which almost wrecked the Community in 1984, were closely related to the perversities of CAP, and so are the budgetary conflicts with the European Parliament. Open conflict, it is true, might help to politicize European issues and thus, ultimately, further political integration (Schmitter 1969). But it is hard to believe that extremely low voter participation at European elections should be understood as the expression of vigorous political demands for more integration, rather than as a vote of non-confidence for the Community.

At the same time, however, the European Community is not only just hanging on'. Direct elections for the European Parliament, which were finally accepted in the 1970s, may not have achieved the political mobilization that had been hoped for, but they are still a symbol of institutional consolidation. In spite of acute conflicts of interest, Britain is still within the Community, and Spain and Portugal have finally been admitted. The European Monetary System did not only survive against many odds, but it is now promoted as the nucleus of a future European Monetary Union with a common currency and a unified monetary policy.

In short, the history of the European Community has not confirmed the hopes, of 'Europeanist' politicians and 'neo-functional' theorists alike, for dynamic processes of deepening and widening functional integration, culminating in the creation of a full-fledged federal state; but the European enterprise has proven much more resilient than the 'realist' school of international relations and the political and scholarly promoters of an Europe des patries would have predicted. Paradoxically, 
the European Community seems to have become just that 'stable middle ground between the cooperation of existing nations and the breaking in of a new one' which Stanley Hoffmann (1966, p. 910) thought impossible.

It is tempting to ascribe the paradox of European integration - frustration without disintegration and resilience without progress - to historical accidents or to the interventions of certain powerful individuals. Instead, I will try to argue in this paper that the European malaise may be systematically explained as the consequence of a characteristic pattern of policy choices under certain institutional conditions. This pattern, the 'joint-decision trap', was first identified in the institutional setting of federal-Länder relations in West Germany. It can be shown that similar institutional conditions are producing similar decision patterns in the European Community.

\section{TWO MODELS OF FEDERALISM}

When 'Europeanist' politicians and social scientists were considering processes of integration that might lead to a 'United Europe', what they had in mind was a federal system fashioned after the American model. What was created, however, were institutional arrangements corresponding more closely to the tradition of German federalism. The fundamental difference between the two models is often misunderstood in Anglo-American treatises on federalism which tend to dismiss the German variant as little more than a camouflage for de facto centralization (Wheare 1960). Even William Riker (1964, p. 123), who recognized the unique characteristics of the German model, finds it hard to fit into his conceptual scheme which classifies federal systems according to the relative weights of the spheres of independent authority of central and constituent governments, respectively. What is missed is the possibility that authority might not be allocated, in zero-sum fashion, to either one or the other level of government, but that it might be shared by both (Johnson 1973). This is what distinguishes the German model from American federalism. Of course, a good deal of sharing, 'marble-cake' or 'picket-fence' like, is going on in the United States as well (Riker 1975), but differences at the constitutional level are nevertheless important.

In both models, the powers of the central government are limited, and constituent governments (the 'states' or the Länder) continue to exercise original governing powers legitimated by democratic elections. In the American model, however, the central government's authority is derived entirely from direct elections of the President and of both houses of Congress, and the federal government is able to rely upon its own administrative infrastructure at regional and local levels whenever it so chooses. In other words, the exercise of federal government functions is formally independent of the governments of the American states, and those functions that have been taken over by the federal government are effectively nationalized. Whatever sharing of functions is going on, is voluntarily granted, and may be withdrawn again by the federal government, as is illustrated by successive waves of the New Federalism'.

In the German model, by contrast, only one house of the federal legislature (the 
Bundestag) is based upon direct, popular elections, while the other one (the Bundesrat) provides for the representation of Länder governments. In practice, all important federal legislation does require concurrent majorities in the Bundestag and the Bundesrat and does depend, therefore, upon the agreement of Länder governments. In addition, the federal government is severely limited in its executive powers, having to rely upon the administrative services of the Länder for the implementation of most federal legislation. On the other hand, the revenue of both, the federal government and the Länder, is generally determined by federal tax legislation which imposes severe constraints upon the financial freedom of action of Länder and local governments. In short: the exercise of most governing functions is shared between the federal government and the Länder governments in West Germany. More specifically, for my present purposes, Länder governments have a significant share in the exercise of many of the important functions of the federal government. It is in this regard that German federalism is most comparable to the European Community.

It is probably fair to say that, even in the heyday of political enthusiasm for European integration in the 1950s, a European union along the lines of the American model of federalism was never a realistic possibility. The Community was created by the action of national governments at a time when their own continuing viability was no longer considered precarious (as it had been immediately after the war). The potentially most powerful motive for federation, common defence, was satisfied by the separate organization of the NATO alliance under US hegemony. What remained was the opportunity pull of economic integration (Scitovsky 1958; Balassa 1962) whose attraction was certainly not sufficient to persuade national governments of the need to commit institutional suicide. While recognizing the advantages of a common European market, they also had every interest in retaining as much control as possible over the substance, direction and speed of future steps towards political integration.

The primacy of national control is reflected in the limited authority of the European Parliament, even though it is now elected directly, and in the fact that the European Commission, the executive body of the Community, does not derive its authority from either the Parliament or from direct elections. Instead, the centre of power has remained in the Council of Ministers, representing national governments, and in the periodic summit meetings of the European Council. In both bodies, the principle of unanimous agreement has prevailed in important matters, providing each member government with an effective veto over European policy decisions affecting its own vital interests. Furthermore, the European Community is without administrative agencies of its own at the regional and local level; it must rely entirely upon member governments to execute its policies. And, of course, the Community has not been invested with its own powers of taxation, depending primarily upon import levies and upon contributions from the revenues of the member states (v.d. Groeben and Mestmäcker 1974; Wallace, Wallace and Webb 1977).

This is not to suggest that there are no significant differences between European institutions and German federalism. In fact, the European Community is much 
weaker in relation to its member governments than the German federal government is in relation to the Länder. Nevertheless, institutional arrangements are sufficiently similar to suggest that the difficulties of European integration might be illuminated by reference to some of the problems of German federalism which have been studied more systematically. The parallelism between European and German institutions appears to be particularly close in those areas of joint policy making which were added rather late (in 1969) to the existing structure of the German federal constitution. In these areas, which have been the subject of empirical and theoretical studies under the label of 'Politikverflechtung' (Scharpf, Reissert and Schnabel 1976, 1977, 1978; Hesse 1978; Schultze 1982; Benz 1985) federal policy making is operating under the same requirement of unanimous consent which prevails at the European level. It is here that the 'joint-decision trap' was first identified.

\section{JOINT POLICY MAKING IN WEST GERMANY}

Under the original scheme of the German federal constitution, most important legislative functions are exercised at the federal level (with the agreement of the Bundesrat), while administrative functions are, with few exceptions, reserved to the Länder. Similarly, in the area of public finance, taxation is almost entirely governed by federal legislation, but tax revenues are shared by Länder and local governments. Even more significantly, the federal share of total public investment expenditures has always remained below 20 per cent.

In the early post-war period, political pressures focusing upon fiscal inequalities between rich and poor Länder gave rise to a formalized system of horizontal and vertical fiscal equalization payments and to a number of extra-constitutional federal grant programmes in such areas as housing and subsidies to agriculture and industry in depressed areas. In the 1960s, these programmes were increased in scope and volume even though their immediate post-war justifications had become less compelling. Instead, it had become clear that some of the important responsibilities of the modern state depended more upon the planning and financing of public infrastructure and public services than upon legislation. To that extent, the relative importance of the governing functions reserved to the Länder was seen to increase, while the legislative powers of the federal government appeared to lose some of their political salience.

At the same time, however, it was widely felt that the action space, and the action perspectives, of Länder governments were too narrowly circumscribed to deal effectively with some of the problems that had become major political issues in the 'reformist' political climate of the mid-1960s. Foremost among these was the perceived need to deal with the 'education gap' (or, even more dramatically, the Bildungskatastrophe) when participation rates in secondary and university-level education were seen to be far lower in West Germany than in other modern countries. Similar needs were perceived in some areas of large-scale public infrastructure, such as urban and inter-urban mass transport, urban renewal or the modernization of the hospital systern. Furthermore, German peasants were about to be exposed to the direct competition of their European neighbours which they 
could only survive, or so it was thought, if the modernization of their farms and of agricultural infrastructure was heavily subsidized. By the same token, it seemed necessary to accelerate and subsidize industrial development in those rural and peripheral areas where agricultural employment was about to decline. In addition, the late conversion of German economic policy makers to the Keynesian philosophy of anti-cyclical demand management emphasized the importance, for economic stabilization, of national controls over the volume and the timing of publicinfrastructure expenditures.

What is important is that these were all policy areas under the dominant influence of the Länder, but that 'enlightened public opinion' was highly sceptical of their willingness, or ability, to provide acceptable solutions. Such scepticism was sometimes, as in education, based upon a preference for nationally uniform solutions over the ideological and religious pluralism of Länder policies. In other areas, such as university or hospital construction, it was thought that the positive externalities of large, central institutions might be ignored by the policy choices of smaller Länder, or that their resource base would be inadequate for projects that could take advantage of important economies of scale. The resource constraints of small or relatively poor Länder were also regarded as obstacles for efficient policy solutions in urban mass transportation, urban renewal and in agriculture (where the problems of small peasant holdings are concentrated regionally). In regional industrial policy, finally, criticism focused mainly upon the undesirable consequences of 'ruinous competition' between Länder which were forced to attract new industrial settlements through ever larger offers of subsidies. What was needed, in short, were joint federal-Länder efforts to mobilize the common resource base, and to exploit the combined action space, of both levels of government for the achievement of common, national goals.

The federal government had, of course, tried to deal with some of these problems through its grant programmes which attempted to provide a degree of co-ordination between Länder policies, to impose some uniform standards, and to equalize some disparities of Länder resources. It was constrained, however, by unresolved doubts about the constitutionality of conditional federal grants in areas within Länder jurisdiction. The whole range of issues was, therefore, entrusted to an expert commission whose final report recommended far-reaching changes in the constitutional arrangements of fiscal federalism (Kommission für die Finanzreform 1966). In the general spirit of 'reform politics' and under the aspects of a 'Grand Coalition', such changes had indeed become politically feasible.

But constitutional change under the West German 'Basic Law' does require twothirds majorities in the Bundesrat as well as in the Bundestag. As a consequence, the constitutional reforms of $\mathbf{1 9 6 9}$ had all the characteristics of a negotiated settlement among independent, sovereign parties. To that extent, they represent an even closer approximation to the decision structures of the European Community than does the original constitution of the Federal Republic. Briefly, agreement was reached on three new areas of joint policy making, each involving the federal government and all the Länder: 
- 'Community tasks' requiring joint planning and joint financing in the areas of university construction, regional industrial policy, and agricultural structural policy (Article 91a, Basic Law);

- federal subsidies to Länder investment programmes in such policy areas as housing, urban renewal, urban transportation or hospitals, and in short-term economic stabilization (Article 104a IV, Basic Law); and

- federal-Länder agreements to collaborate in the planning of primary and secondary education and in research financing (Article 91b, Basic Law).

Of these, primary and secondary education turned out to be the ideologically most controversial policy area. As there was very little federal money at stake (apart from federally financed 'model experiments'), 'progressive' and 'conservative' Länder felt free to engage in all-out conflict over their educational philosophies. For once, the Social-Liberal federal government was also willing to take a clear cut partisan position, so that the first drafts of the 'integrated education plan' turned out to be remarkably progressive documents. Unfortunately, however, they could not be adopted at the level of the heads of government, where the agreement of nine (out of eleven) Länder prime ministers was formally required. As a consequence, existing educational policies remained unchanged while efforts continued to reach agreement over ever more watered-down versions of the educational plan. In the meantime, public enthusiasm and political support for educational reforms began to erode, and so did financial resources for education at the onset of the economic and fiscal crisis after 1974. Predictably, the difficulties of reaching agreement in the face of acute political conflicts led to outcomes which frustrated not only the qualitative goals of progressive educational reformers, but also the quantitative goals shared by both the progressive and the conservative members of the education establishment (see Heidenheimer, Heclo and Teich-Adams 1975, 1983). In the end, the whole enterprise was abandoned in 1982 (BMBW 1982).

The lesson was not lost on others, and the internecine ideological battles of the educationists were not repeated elsewhere. Realizing the importance of presenting a united front toward an outside world of political 'generalists' in chancellories, finance ministries and parliamentary budget committees, agreement became the primary goal itself. Thus, the specialist ministries responsible for federal-Länder negotiations at both levels developed decision rules approaching unanimity even in areas where, by law, majority decisions would have been possible. Perhaps still more important was a perception of common interest which prevented even those Länder that would have benefited in the particular case, from voting with the federal government as long as there was no nearly unanimous agreement among all of them.

Länder solidarity thus prevented the federal government from playing off the interests of some Länder against others in forming the 'minimum winning coalitions' which coalition theory would have predicted under such circumstances (Riker 1962). In fact, the 'cartelization' of Länder interests has been observed even in the field of research policy, where independent action by the federal government and 
individual Länder would have been entirely feasible and probably more effective (Bentele 1979), or in the planning of federal highways, where the federal government is legally empowered to decide unilaterally, but is in fact dependent upon the expertise of highway administrations at the Land level (Garlichs 1980). If even such weak linkages could bring about the application of de facto unanimity rules, the underlying mechanisms must be powerful indeed, and they have been operative long before the federal constitutional court did write the unanimity requirement into law for some of the joint-programme areas (BVerfGE 1975, p. 96). Perhaps this might give pause to those who tend to regard unanimity in the European Community as a merely technical problem which could be solved by a more authentic interpretation of the Treaty of Rome.

The substantive outcomes of joint decision making in West Germany may be roughly described as follows. During the early 1970s, joint programmes were remarkably successful in increasing the financial resources available for their respective policy areas, and in defending their expenditure levels even after 1975, when many other programmes were severely curtailed in response to the fiscal crisis arising from the economic recession. As a matter of fact, the share of joint programmes among total federal expenditures increased from 6.8 per cent in 1970 to 9.5 per cent in 1974 and 11.2 per cent in 1977 (BMF 1985, tables 1 and 6). In the following years, however, the hopes associating joint decisions with new opportunities for more effective public policy making gave way to a growing sense of disappointment and frustration, first among political and bureaucratic insiders (Scharpf, Reissert and Schnabel 1977), but then among the wider public as well. Instead of utilizing the joint action spaces of the federal government and the Länder for the purpose of more active and creative problem solving, joint programmes were increasingly seen as being either inefficient, or inflexible, or unnecessary and, in any case, quite undemocratic.

On the basis of our detailed studies of decision processes and outcomes in the various joint-policy areas, we tend to agree with these criticisms and, indeed, we may have contributed something to their overall thrust and credibility. Obviously, a satisfactory restatement of our findings would be beyond the scope of this article, but the gist of our analyses might still be conveyed through a few illustrative examples.

As far as the alleged inefficiency is concerned, it is claimed that joint programmes tend toward 'overspending' even by their own narrow criteria of optimality, and that the inter-regional distribution of funds tends to violate even their own criteria of allocative efficiency. The first claim is, perhaps, best illustrated by the joint programme to finance capital investments in the hospital sector. As German health insurance regulations allow hospitals to charge their full operating costs to the insurance system, hospitals had every incentive to increase their capital expenditures, once the joint programme provided for the full reimbursement of investment costs. The Länder, on their part, did not wish to forfeit their allotted share (determined by a per capita formula) of the available federal funds - with the predictable outcome of rapidly increasing investments even in areas where hospital services were fully adequate. As a result, there are now considerable excess capacities in 
the hospial sector (and rapidly escalating deficits of the health insurance system). Apparently, the joint programme had eliminated existing financial constraints without being able to introduce functionally equivalent mechanisms of rational planning and efficient allocation (Schnabel 1980).

The per-capita formula for distributing federal funds among the Länder, which prevails not only in hospital finance but in most other joint-programme areas as well, is obviously also a source of allocative inefficiency whenever there should be significant inter-regional differences in the need for, or the existing supply of, particular public services. A glaring example was agricultural investment subsidies. There the established distribution of federal funds, favouring the big-farm regions of Northern Germany, was found to be grossly unresponsive to criteria of actual need and programme effectiveness by a programme planning and evaluation group set up by the ministers of agriculture themselves. Nevertheless, redistribution in favour of the disadvantaged small-farm and hill regions in Southern Germany proved impossible under the conditions of joint decision making.

The example of agricultural subsidies might also be used to illustrate the alleged inflexibility of joint decision making. Even more to the point, however, would be the case of regional industrial policy. Evolving from a tradition of ad hoc federal subsidies to depressed areas in the early post-war period, this had become the jointpolicy area with the greatest claim to substantive and procedural rationality by the early 1970s. Far from distributing federal funds evenly among the Länder, or according to some arbitrary or traditional formula, regional policy managed to achieve agreement on economic criteria for subsidization and on the use of sophisticated econometric analyses for the designation of assistance areas. In the main, these were located along the eastern boundaries of the Federal Republic and in certain under-industrialized areas throughout the country.

The reputation for allocative efficiency suffered a severe blow, however, when regional industrial policy was unable to respond to the economic recession after 1974. Its impact was most severe in some of the old industrial regions, which in the past had been too prosperous to be included among the assistance areas. Now that their unemployment rates becarne much worse than those of many rural areas which were traditionally subsidized, agreement on an inter-regional redistribution of funds could not be reached. The best that the federal government could achieve was acquiescence of the beneficiaries of the status quo when additional federal funds were temporarily made available to some regions dominated by the newly depressed automobile industry. In the following years, similar ad hoc programmes were introduced for the Saar region, for regions dominated by the steel industry generally, and for the Bremen area suffering from the simultaneous decline of steel and ship building. Thus, regional policy is still aimed at under-industrialized peripheral areas while a growing number of special assistance programmes are used to subsidize declining industrial regions without curbing subsidies to peripheral regions. Instead of the necessary reorientation of assistance criteria in response to fundamentally changing economic circumstances, the result has been a cumulation of conceptually contradictory assistance programmes, reintroducing just that pattern 
of inter-regional competition for the subsidization of mobile firms which the original programme had been designed to eliminate.

The claim that some joint programmes may in fact be, or have become, unnecessary, is derived from a normative analysis of the type of problems that might justify joint federal-Länder action in the first place. Some of these justifications, such as the existence of significant inter-jurisdictional externalities, of economies of scale, or of redistributive goals (Oates and Wallace 1972; Breton and Scott 1978) seem to be as applicable now as they were when federal grant programmes originated in the early post-war period. In other areas, however, such as housing or urban renewal or, perhaps, local road construction, we have argued that the objective need for any federal involvement had disappeared over time. At least after the mid-1960s, aggregate disparities between the Länder had been sufficiently equalized to eliminate the need for federal intervention (and the fact that in these areas federal money is allocated to the Länder on a per-capita basis tends to confirm our judgement). At the same time, some of the joint programmes, in such areas as university construction, hospital investments and urban mass transport, seem to have achieved most of their original goals, so that the remaining externalities and economies of scale could be handled within Länder jurisdictions. In many areas, therefore, it has become difficult to identify any purposes of federal involvement which could not be equally well pursued at the Länder level. On the other hand, the degree of red tape generated by the cumulation of regulations in jointly financed programmes seems to be so high that the costs of delays and inefficiencies of programme implementation have themselves become a major source of irritation (Lehner 1979, 1979a; Zeh 1979; Borell 1981).

In addition to being allegedly inefficient, inflexible and, sometimes, unnecessary, joint programmes are also often criticized for their undemocratic character, confronting parliaments with the faits accomplis of bureaucratic negotiations between the two levels of government (Klatt 1979). To some extent, this criticism seems trivial, as some loss of parliamentary control is necessarily involved in all forms of intergovernmental bargaining. Parliaments may ratify or reject the outcome, but they will rarely be able to exercise direct control over the negotiation process itself - except by Carl Friedrich's 'rule of anticipated reaction'. To some extent, it may also express unhappiness with the political conditions of German federalism, combining party-political confrontation in the Bundestag with the need to reach all-party agreement in the Bundesrat, at least until 1982 (Lehmbruch 1976). But the criticism may also cut deeper. The fact that certain programmes are jointly financed by two (or sometimes three) levels of government reduces their opportunity costs at each level. In comparison to competing programmes which would have to be financed entirely from one source, joint programmes thus seem to have an 'unfair' advantage at each level. One of the consequences is the tendency to 'overspend' on joint programmes, which was discussed above as one of the sources of inefficiency. Another is the distortion of 'real' political preferences at the local and Land levels whenever some programmes, but not all, are heavily subsidized by the federal government. Under such conditions, joint programmes may indeed become offers which a Land or a city 'cannot afford to reject', and, thus, a serious 
constraint upon local and regional democratic control (Späth et al. 1979). Finally, the role of Länder governments in federal legislation has tended to increase the salience of 'federal' issues in Länder elections at the expense of regional issues (Heidenheimer 1958; Hesse 1962; Lehmbruch 1976; Fabritius 1978; Abromeit 1982).

Taken together, these four lines of critical attack have seriously weakened the political attractiveness of joint programmes in West Germany since the mid-1970s (Schmidt 1980; BMF 1982). In addition, there have been specific reasons for disenchantment at each level. The federal government, for instance, found itself frustrated by the inflexibility of joint programmes when it tried to respond to the economic recession through fiscal redistribution. Instead of adjusting existing programmes as needed, it was forced to pay for additional programmes in regional industrial policy as well as in the field of public infrastructure investments (Nöllig 1977, p. 391). Furthermore, empirical research has demonstrated that increases in the volume of joint programmes were relatively ineffective as an instrument of anti-cyclical fiscal policy (Knott 1981). The Länder and, even more so local governments, tended to shift expenditures from one sector to another rather than to increase the overall level of their own spending as the federal government increased the volume of its grants (Reissert 1984). Thus, the federal government has again reduced its financial commitment to joint programmes from 11.2 per cent of total expenditure in 1977 to 8.2 per cent in 1980 and 7.4 per cent in 1983 (BMF 1985). One area, hospital finance, was even taken out of joint-finance arrangements altogether in 1984 (BMF 1985, pp. 43-4).

Resistance of the Länder against such cutbacks has been remarkably muted. It seems that some of the 'rich' Länder have by now concluded that joint programmes had been a bad idea to begin with, and that they would be better off regaining their freedom of independent action. Poor Länder, on the other hand, have been disappointed by the absence of significant redistributive effects (because of the per capita allocation of federal funds in most programmes). Furthermore, the standard of equal treatment in all programmes implied that rich and poor Länder had to comply with the same matching requirements, which meant that some of the poorest Länder were in fact unable to claim their allotted share of federal funds during the recession. They, surely, would have been better off if the earlier practice of bilaterally negotiated federal grants would have continued.

What has been described is, however, mainly the response of 'policy generalists' in the federal and Länder chancellories, ministries of finance and parliamentary budget committees. They seem now committed to resist all suggestions for establishing new joint programmes. But such suggestions are still forthcoming from the vertical alliances of 'policy specialists' who are pushed toward federalLänder arrangements by the original logic of a constitution under which the fragmentation of functions can only be overcome through the sharing of responsibilities. In a period of general disenchantment with activist philosophies of state intervention, such pressures may be resisted. But the underlying logic is still powerful enough to prevent the wholesale dismantling of existing joint programmes. 


\section{JOINT POLICY MAKING IN THE EUROPEAN COMMUNITY}

In some areas, the similarities between European policy making and joint policy making in Germany are so obvious as to be trivial. When small European programmes are simply 'tacked on' to ongoing national programmes, they will add to the bureaucratic and political costs of vertical co-ordination (Hrbek 1979) without being able to change national policy priorities very much. The only interesting question is whether European funds will add to, or substitute for, national expenditures, but the ability of national dogs to wag the European tail is not really in doubt. Thus, it is not at all surprising that decision patterns corresponding closely to the model of joint programmes in Germany have been identified in studies of the European Regional Fund (Bruder 1983; Noé 1983; Martins and Mawson 1982) and of the Social Fund (Laffan 1983), and that they also seem to govern the regional allocation of European R\&D funds (Steinle and Stroetmann 1983).

The more interesting question is whether such similarities can also be found in Common Agricultural Policy which, by common consent, is the one area in which the European Community is approaching the full powers of a federal government. At least in the field of market and price regulations, CAP is not 'add on' but has replaced national programmes altogether, and its financial volume of 16.5 billion ECU in 1984 (amounting to 65 per cent of Community expenditure) is anything but trivial. Here, if nowhere else, we surely have a genuine European dog.

At the same time, CAP is formulated in a decision structure that is strikingly similar to that of joint programmes in West Germany. In both cases, important policy functions were moved up to the next-higher level of government, while their exercise remained dependent upon the unanimous agreement of member governments (Feld 1980). As in the German case, CAP was originally praised as a successful solution to the obvious co-ordination problems of national agricultural policies in an internationalized market for agricultural products, and it is now increasingly criticized for being outrageously wasteful as well as ineffective in terms of its own original goals. Most of the criticism is levelled at agricultural market policy (as distinguished from agricultural structure policy): it has burdened European consumers with food prices far above the world market; it has burdened European tax payers with a rapidly rising volume of subsidies; it is responsible for growing surpluses of agricultural production in Europe which must either be destroyed or dumped on the world market at enormous losses; and despite all these exertions, CAP was not successful in achieving its primary goals, a truly common market for agricultural products in Europe and adequate standards of living for low-income farmers (Body 1982; Rodemer 1980).

The alleged failures of CAP are directly related to its basic policy choices. At bottom, they can all be derived from the decision to protect and raise the income of European farmers through a system of price supports, rather than through direct income transfers. Once this choice had been made (which was probably inevitable in the light of the traditional agricultural protectionism of the founding members of the community), the further characteristics of CAP could be derived from the 
underlying structure of national interests (German and French, in particular) within the logic of unanimous decision making.

Compared to Germany, France had a much larger and, on average, more productive agricultural sector and significantly lower food prices. As a foodexporting country, France was vitally interested in free access to the larger European market, especially as she was likely to suffer from the German strength in industrial exports. German peasants, on the other hand, had little to gain and much to fear from a common European market for agricultural products, unless it was possible to maintain the high price levels prevailing in Germany for the typical products of German agriculture (mainly dairy products, meat, grains and sugar). The compromises which were reached after protracted negotiations, and dramatic Franco-German confrontations, predictably managed to accommodate both positions: the European market was to be opened to French producers (which precluded the general introduction of a system of production quotas), but prices were to be maintained at levels close to those prevailing in West Germany through a system of import levies and minimum prices (at which the European Agricultural Guidance and Guarantee Fund' has to purchase farm products that cannot be sold on the open market). As these 'intervention prices' were fixed far above the world market, and also far above production costs in the more productive agricultural regions in Europe, increasing agricultural surpluses were inevitable. The results were escalating guarantee payments which rapidly exceeded the revenue obtained through import levies. Far from being self-financing, the guarantee fund did require enormous subsidies, rising to more than 6 billion ECU (or about 75 per cent of the total community budget) by 1976, to almost 12 billion ECU in 1980 and to 16.5 billion ECU in 1984 (DIW 1984).

But even at that price, an effectively unified agricultural market could not be realized because of divergent national interests in the face of continuing variations in the exchange values of national currencies. When the French franc was devalued by 11 per cent in 1968, France was not willing to let food prices rise accordingly. Instead, food imports were subsidized and French agricultural exports penalized at the border. And when Germany revalued the Deutschmark later in the same year, the precedent was invoked to avoid price reductions for German farmers. A similar pattern was followed on many later occasions. The border levies on imports from low-value currency countries, and the border subsidies paid to exports from high-value currency countries, produced a 'green exchange rate' differing more and more from the official exchange rates among the currencies of member countries. As a consequence, the internal price level for agricultural products was relatively higher in the high-value currency countries such as Germany or the Netherlands, and so was the amount of EC subsidies flowing into these countries. Thus, the incentives for agricultural overproduction, which originally were the largest in France, have later tended to favour German and Dutch producers (Feld 1980).

At the same time, CAP was also unable to achieve the income goals for which it had been instituted. Price support for agricultural products meant that fewer people were leaving the farms than had been expected, so that per capita farm 
incomes still were not able to catch up with average earnings. Furthermore, while large and productive farms did extremely well at CAP prices, price support alone could not significantly reduce the economic plight of small peasants in agriculturally disadvantaged areas where industrial jobs are also scarce (Balz et al., 1982). A special subsidy programme for hill farmers does provide some income support, but its volume is minimal compared to the expenditures on price support.

As in the German example, the growing disappointment and frustration over CAP is beginning to have an effect. The United Kingdom and, to a lesser extent, the Federal Republic, as the two large net contributors to the Community budget, have been trying to apply financial brakes to the vicious cycle of agricultural subsidies and surpluses. The formal opportunity to do so was provided by the growing budget deficit of the Community requiring an increase of the VAT levy (which also required unanimous agreement). For several years, CAP barely managed to squeeze by without re-examination because rising prices in the world market for agricultural products had unexpectedly reduced the need for subsidies. But in the spring of 1984, some adjustment had become inevitable. It took the form of a relatively permissive quota system for milk production and a more decisive effort to eliminate border equalization subsidies and levies in order to bring the 'green exchange rate' more into line with official exchange rates (Jürgensen and Schmitz 1984). Obviously, this last measure would hurt producers in high-value currency countries, such as West Germany, and it is perhaps not surprising that the immediate German response (accepted by the Community) was to provide national subsidies to make up for these losses (DIW 1984a). Thus, the Community had eased its budgetary problems somewhat, but at the sacrifice of one of the most cherished principles of European integration - the elimination of national farm subsidies and their replacement by what should have been a common agricultural policy.

But even with the 1984 compromise, the future of CAP is far from assured. Incentives for overproduction have not been eliminated, quota systems have not worked well in other areas, and the spill-overs from exchange rate fluctuations are likely to disturb the regulated markets for agricultural products in the future again. Furthermore, the entry of Spain and Portugal, with large agricultural surpluses of their own, will upset the precarious equilibrium of the Community budget even though their major products are not as heavily subsidized as the Northern' products that were the subject of the original Franco-German compromise.

Nevertheless, judging by the past record as well as by the current 'revealed preferences' of national governments, it is more likely that CAP will hang on, even if its original logic and purpose should be distorted beyond recognition, rather than that it will be either scrapped or reorganized into a more defensible policy system. In the following sections, I will attempt to develop an analytical argument that might explain both the substantive deficiencies and the persistence of joint policy making in the Federal Republic and in the European Community. 


\section{JOINT DECISIONS AND THE PATHOLOGY OF PUBLIC POLICY}

The contribution of institutional arrangements to the substantive deficiencies of joint policy making in West Germany and in the European Community are related to two simple and powerful conditions:

- that central government decisions are directly dependent upon the agreement of constituent governments; and

- that the agreement of constituent governments must be unanimous or nearly unanimous.

The German experience further suggests that the first condition may imply the second one, and that unanimity will evolve even in the absence of formal requirements. This might not be so if the number of constituent governments were very large (raising the transaction costs of unanimous agreement) or if the central government were allowed to negotiate bilateral agreements with each of the member governments separately. But in multilateral negotiations among a small group of governments over uniform regulations which will apply to all of them, unanimity seems a rational rule to follow for risk-averse participants even if they might benefit from majority decisions in the individual case (Everling 1980, p. 221). Nevertheless, it is useful to distinguish between the two aspects of 'joint decisions', their intergovernmental character, and the unanimity rule.

The importance of the inter-governmental aspect becomes clear when one compares the representation or regional interests in the US Senate and in the German Bundesrat. In both cases, the territorial distribution of societal interests is emphasized at the expense of other dimensions of multi-dimensional interests (and at the expense of the Rousseauean ideal of the 'general interest'). But while US Senators, ideally, represent only the interests of their constituents (mediated through their own interest in re-election), the Bundesrat also (or, rather, primarily) represents the institutional self-interests of Länder governments. Thus, Claus Offe's 'Interesse des Staates an sich selbst' (1975, p. 13) will be introduced twice, as 'withinput' and as 'input' in Eastonian language (Easton 1965, p. 54), into the political processes of the central government. One might expect, therefore, that the policy output of joint decision systems, when compared with unitary governments or the American model of federalism, will be less responsive to constituency interests and more oriented toward the institutional self-interests of governments and their 'bureaucratic convenience' (Tullock 1965; Niskanen 1971). More important, however, is the fact that these governmental interests are not, in the strict sense, 'represented' at all. Instead, they are direct participants in central decision processes. In that regard, what we have is a system of direct, 'participatory' democracy without any of the safeguards for detached reflection on the general interest, by non-instructed delegates, which has been emphasized by theorists of representative government ever since Edmund Burke (Scharpf 1970). Also, as far as member states are concerned, there is none of the 'generalization of support' 
which Talcott Parsons (1967, pp. 231-4) thought necessary for the maintenance of effective government in a democracy. In joint-decision systems, the central government is not free to respond creatively to external demands, or to anticipate future consensus; its actions are determined directly by the immediate self-interests of member governments.

Nevertheless, differences are important. While decisions of the European Community are completely determined by the outcome of negotiations among member governments, the German federal government has a political identity, resources and strategic and tactical capabilities of its own. It cannot adopt and implement effective public policy without Länder agreement, but it can design and pursue bargaining strategies against the Bundesrat which the European Commission cannot similarly pursue against the Council of Ministers or the European Council.

But the German federal government is also paying a price for its greater strategic autonomy: being able to bargain with the Länder over policies which it considers essential to the national interest (or to its own political survival), it still must obtain their agreement. Sometimes it may be possible to design 'win-win solutions' which are intrinsically attractive to the Länder as well. More often, its original policy proposals were watered down in substantive compromises. And if the federal government insisted upon its objectives, it often had to buy support for national policies at the expense of permanent improvements of the institutional and financial position of the Länder. Thus, just as the emperors of the Holy Roman Empire were forced to expend their dynastic possessions and, finally, the imperial prerogatives, in order to maintain the loyalty of their vassal princes, so the German federal government has seen its share of total revenue reduced from 53 per cent in 1970 to 48 per cent in 1983 (BMF 1985, Table 2). As there was, of course no corresponding reduction of federal responsibilities, the total volume of the federal debt increased from 54 per cent of expenditures in 1970 to 105 per cent in 1980, while Länder debts increased only from 62 per cent to 76 per cent of expenditure during the same period (Simmert and Wagner 1981, p. 455). Being entirely the creature of member governments, the European Community could not, of course, be similarly exploited by them.

But what are the implications of inter-governmentalism for the substance of public policy? The most clear-cut connection seems to exist with the alleged tendency of joint programmes to increase expenditures beyond the level that would be politically acceptable within a unitary government. This tendency seems to follow directly from 'rational' calculations of financial costs and political benefits at each level of government. If we assume that elected officials are sensitive to interest group pressure at all levels of government, and that interest groups are capable of presenting demands and exerting pressure at each level as well, then the political benefits associated with positive responses to interest group demands will be fully realized at each level, even if the response is delivered by a joint programme. On the other hand, if the joint programme is also jointly financed, its costs will be reduced accordingly for each level of government. Compared to single-government decisions, therefore, joint decisions have politically more attractive cost-benefit ratios. To put it crudely, more votes can be bought for less money at each level. 
The conditions assumed in this model are closely approximated in West Germany, where governments at the local, regional and federal levels are dependent upon direct elections, where interest groups are active at all levels, and where joint programmes have matching requirements involving at least two, and usually three, levels of government in their financing. Under such conditions, the separate calculation of costs and benefits at each level will indeed suggest a relative increase of expenditures on joint programmes at the expense of programmes which have to be financed entirely by a single level of government. Our interviews in Germany have shown that active participants in policy processes are fully aware of these mechanisms - which explains why the vertical coalitions of interest groups, politicians and bureaucrats specialized in a certain field, are completely unanimous, in spite of all other internal disagreements, in defending the privileged status of their policy field as one of the joint programmes. But what about CAP, where at least two of the conditions assumed above seem to be missing? First, there are no matching requirements in the core areas of price subsidies, so that expenditures are all on the European level. Second, even though there are now direct elections to the European Parliament, it is obviously impossible to interpret CAP as the response of vote-maximizing politicians at the European level. By contrast to the German model, where all levels of government are profiting from joint programmes, it seems that the European Community has to bear the full costs without capturing any of the political benefits associated with CAP.

But, of course, it is national, rather than European, politicians who are determining CAP choices. And their cost-benefit calculations are obviously quite different. If we differentiate, for the sake of clarification, between the calculations of policy specialists and of generalists (say, national ministers of agriculture and national ministers of finance), the former must see CAP as an entirely free good whose production they have every incentive to maximize. For the finance ministers, on the other hand, a self-interested response would seem to depend mainly on the net position of their country with regard to the EC budget. Net beneficiaries would surely have less reason to object to the cancerous growth of CAP than net contributors. Thus it must be the acquiescence, or resistance, of net-contributing countries, the Federal Republic and the United Kingdom in particular, which explains the growth of the CAP.

For most of the period since the commencement of CAP in the middle of the 1960s, it has been acquiescence. The Germans were, and are still (Höhnen 1984) aware of the fact that they had to buy CAP in exchange for the common market for industrial products which favoured German exports. And they also know that the high price levels prevailing under $\mathrm{CAP}$, which are the cause of overproduction and, hence, of rising subsidies, were adopted at their own insistence to protect the prevailing income levels of German farmers. Thus, the one country that should have had a financial interest in limiting CAP was among its original supporters for reasons unrelated to the specific incentives and constraints of its decision structure.

Of course it is true that the Germans, like everybody else, had vastly underestimated the dynamics of price support, overproduction and escalating subsidies 
in European agriculture - but when they found out, they were already caught in the rigidities of an ongoing decision system based upon the principle of unanimous agreement. Unanimity is generally considered as the decision rule which is most in conformity with the methodological individualism of public choice theory. If collective decisions depend upon the voluntary agreement of all members of the community, they are also likely to meet the welfare-theoretical criterion of Pareto optimality (Buchanan and Tullock 1962). Difficulties are likely to arise from increasing transaction costs in large communities and from the disruptive consequences of 'strategic voting', when members are tempted to conceal their true preferences for public goods in order to exact concessions in the allocation of costs (Buchanan 1975, p. 41). Given the small number of member governments, and the transparency of their (institutional and constituency) interests, neither problem should be of great importance in German federalism or in the European community.

What public-choice theorists have generally neglected, however, is the importance of the 'default condition' or 'reversion rule', which was recently pointed out by Elinor Ostrom (1984). The implications of unanimity (or of any other decision rule) are crucially dependent upon what will be the case if agreement is not achieved. The implicit assumption is usually that in the absence of an agreed decision there will be no collective rule at all, and that individuals will remain free to pursue their own goals with their own means. Unfortunately, these benign assumptions are applicable to joint decision systems only at the formative stage of the 'constitutional contract', when the system is first established. Here, indeed, agreement is unlikely unless each of the parties involved expects joint solutions to be more advantageous than the status quo of separate decisions. Parties with no interest in joint decisons will either opt out or will have to be bribed with side payments. Thus, the original agreement is indeed likely to be in everybody's interest, which may explain the general sense of satisfaction, enthusiasm and optimism associated with the early years of both European integration and joint policy-making in West Germany.

The 'default condition' changes, however, when we move from single-shot decisions to an ongoing joint-decision system in which the exit option is foreclosed. Now non-agreement is likely to assure the continuation of existing common policies, rather than reversion to the 'zero base' of individual action. In a dynamic environment, the implications for the substantive quality of public policy are obvious: when circumstances change, existing policies are likely to become sub-optimal even by their own original criteria. Under the unanimity rule, however, they cannot be abolished or changed as long as they are still preferred by even a single member. Thus, the association of unanimity and Pareto optimality emphasized by publicchoice theorists seems to be restricted to single-shot decisions. In ongoing decision systems, by contrast, unanimity is likely to be associated with a systematic deterioration of the 'goodness of fit' between public policy and the relevant policy environment - unless there should be very powerful mechanisms of consensus formation.

The problem is even more serious when the freedom of individual action is entirely eliminated even in areas where there is no prior agreed-on policy at all. 
Obviously, this is not a necessary characteristic of joint-decision systems: Federal constitutions usually allow for the 'concurrent jurisdiction' of member governments as long as federal legislation has not 'pre-empted the field'. But if joint-decision systems are specifically set up to regulate externalities of member-government policies, or to establish a truly common market, then the field must be pre-empted (Weiler 1982). That also means, however, that member governments will be precluded from dealing individually with pressing problems even if the Community cannot agree on an effective solution.

In short, joint-decision systems are doubly vulnerable to the consequences of non-agreement: they may be incapable of reaching effective agreement, and they may lose the independent capabilities for action of their member governments. As a consequence, their overall problem-solving capacity may decline - certainly in comparison to a unitary state of similar size and resources, but possibly also in comparison to smaller states, with less resources but an unfettered ability to act individually. Everything depends, therefore, upon the capacity of ongoing jointdecision systems to generate, maintain and adjust agreement on joint policies in the face of inevitably differing interests, goals and perceptions, and in the face of inevitably changing circumstances.

\section{'PROBLEM SOLVING' AND 'BARGAINING' IN JOINT DECISIONS}

Obviously, effective agreement is problematical under all conditions (even Robinson Crusoe had difficulty in making up his mind). But in decision theory it is increasingly recognized that the nature of the problem, and its inherent difficulty, varies systematically with the modalities under which effective agreement must be achieved. One dimension of these modalities is defined by the applicable decision rules (unanimous, majority or unilateral/hierarchical decisions). The other dimension is defined by the prevailing orientation of participants, and by the strategies which they are expected to employ in order to influence the outcome. There is, as yet, no agreement on terminology: March and Simon (1958) discuss different 'processes of conflict resolution', Richardson (1982) refers to different 'styles of decision-making', while Boboma (1976) proposes to distinguish among different 'power systems'. But substantive agreement on the distinctions actually subsumed under these different labels seems to be remarkably high: March and Simon's (1958, p. 129) four-fold classification of 'problem-solving', 'persuasion', 'bargaining' and 'politics' is overlapping with Olsen's 'problem solving', 'bargaining', 'mobilization' and 'confrontation' (Olsen et al. 1982). And it also seems possible to relate Bonoma's (1976) discussion of 'bilateral', 'mixed' and 'unilateral power systems' and Bühl's (1984) emphasis upon dominant orientations toward 'values', 'interests' or 'power' to these more process-oriented classifications of decision making.

For present purposes I will adopt Richardson's generic label of 'decision styles' and a three-fold distinction between 'problem solving', 'bargaining' and 'confrontation'. At the most general level, each of these 'styles' may be characterized by specific value orientations and sanctioning strategies: 'problem solving' by the appeal to common ('solidaristic') values and by resort to ostracism and exclusion as the 
ultimate collective sanction; 'bargaining' by the appeal to the individual self-interests of all (necessary) participants and by resort to incentives; and 'confrontation' by the appeal to the interests of the dominant individual or coalition and by resort to power and coercion as the ultimate sanction. While these definitions are logically independent from the applicable rules of decision (prescribing 'unanimous', 'majority' or 'unilateral/hierarchical' assent for effective decisions), that does not preclude substantive interdependence. Obviously, 'confrontation' under majority rules means something different from 'confrontation' under the unanimity rule. In each case, therefore, it is the specific combination of a decision style with a decision rule which will determine the characteristic capacity of the decision system to reach effective agreement on collective policy choices.

Returning, after this exercise in conceptual clarification, to the problems of conflict resolution and consensus formation in joint-decision systems operating under the unanimity rule, one might consider 'confrontation' as the least promising style of decision. As German education reformers had to learn the hard way, there is no sense in trying to push people around if you are dependent upon their agreement in the end. Indeed, Gerhard Lehmbruch (1976) has based his incisive analysis of the political dynamics of German federalism during the period of the Social-Liberal coalition squarely upon the idea that there was a fundamental contradiction between the confrontation politics staged by the federal government against the parliamentary opposition, and the manifest need to obtain all-party agreement in the Bundesrat for all major policy initiatives. But, of course, confrontation under the unanimity rule is a highly asymmetric game, and there is no reason to assume that the opposition parties should have been equally unhappy about its outcomes.

More generally, 'confrontation' under the unanimity rule seems highly serviceable for participants interested in preserving the status quo (or in exacting maximum concessions for their agreement to policy changes). It is the proponents of policy change who depend upon agreement, and who are likely to suffer defeat when a confrontational decision style prevails. And even here there are differences, depending upon whether the exit option is available, and whether it can be employed as a credible threat. In German federalism, exit is generally foreclosed in regulatory programmes, but individual Länder might opt out of matching-grants programmes. In the European Community, however, 'secession' also continues to be a live political option which may be invoked in confrontation strategies. Both Charles DeGaulle and Margaret Thatcher, have been able to achieve significant policy changes in this fashion. But, of course, secession might not have quite the same threat value for all member countries, and its credibility might be quite low in the case of countries whose economic stake in, and political attachment to, the Community is known to be very high. On the whole, therefore 'confrontation' is indeed the least promising decision style for policy changes and institutional reforms in joint-decision systems. If progress is to be achieved at all, it must be achieved within a 'bargaining' or 'problem-solving' framework in which it is not possible to short-circuit the requirement of unanimous agreement, and to impose solutions unilaterally.

Of these 'bargaining' seems to be the less demanding and, hence, more robust 
decision style. It is premised upon the assumption that participants will pursue their individual self-interest, and that agreement can only be obtained if its anticipated utility is at least as high for each participant as the anticipated utility of no co-operation (Nash 1950). 'Problem solving' in its pure form, on the other hand, is premised upon the existence of a common utility function and the irrelevance of individual self-interest for the decision at hand - either because individual interests are submerged in the common interest, or because they are effectively neutralized through institutional arrangements separating the pursuit of common goals from the distribution of costs and benefits. Furthermore, while disagreement may be an entirely acceptable outcome in 'bargaining', it is not so in 'problem solving', where the common commitment to the common goal would de-legitimate open non-co-operation. But that does not mean that agreement should be more easily obtained: battles over the proper definition of the common goal, or over appropriate strategies, might indeed be more bitter and divisive than the search for mutually agreeable compromises at the 'bargaining' table (Bonoma 1976).

Two further points need to be emphasized. First, the distinction between bargaining' and 'problem solving' is not logically related to the difference between zero-sum and non-zero-sum games. Indeed, in the prototypical exchange situation analyzed by Nash (1950), bargains will only be struck if individual valuations of tradeable goods are sufficiently different to allow both parties to increase their respective utilities. Conversely, zero-sum conflicts over the distribution of limited resources are perhaps better resolved in the 'problem-solving' style by recourse to common norms and values and, perhaps, to adjudication, rather than by pure 'bargaining', where the have-nots are without recourse against the distribution of original 'endowments'.

Second, just as 'mixed-motive games', combining elements of zero-sum and positive-sum situations, are more important in real-world situations than either of the pure game forms (Bacharach and Lawler 1980), so is there also a wide overlap between 'bargaining' and 'problem solving' in real decision processes. The empirical distribution may be highly asymmetrical, however. While pure 'bargaining' seems to be quite frequent in practice, it is unlikely that there will be many 'problemsolving' interactions without an admixture of 'bargaining' behaviour. Thus, decision styles may evolve and change over time in real-world decision systems, but it is possible that their dynamics will have only one stable resting point at the bargaining' end of the continuum.

In discussing this hypothesis, it seems useful to distinguish the pursuit of common interests from that of a class of individual interests whose realization does depend upon co-operation. In the case of jointly produced private goods it is indeed likely that purely self-interested exchange relationships may develop into stable networks of mutual dependence in which participants will anticipate, and respect, the selfinterest of their partners (Scharpf 1978). But that will not, by itself, move interactions out of the bargaining' mode. The same is true of that 'cooperation among egoists' which Axelrod (1981) discovered in computer-simulated iterations of the Prisoners' Dilemma and in similarly structured real-world situations (Axelrod 1984). The Prisoners' Dilemma is, after all, one of the 'paradoxes of rationality' (Howard 
1971) in which narrowly selfish calculations will lead to sub-optimal outcomes in terms of individual self-interest. What has been discovered, following theoretical work in biological evolution (Trivers 1971; Dawkins 1976), is a certain strategy ('Tit-for-Tat') which is co-operative but non-exploitable, and which does so well in long iterations of the game that it tends to drive other strategies out of competition. Thus, co-operation eliminates the 'paradox' and allows participants to return to the rational pursuit of their individual self-interests.

By contrast, what is necessary for the 'problem-solving' style to emerge is an orientation towards common interests, values or norms which are distinct from the individual self-interest of participants (Bonoma 1976, p. 507) and which, therefore, may facilitate voluntary agreement even when sacrifices in terms of individual self-interest are necessary and cannot be immediately compensated through 'side payments' or 'package deals'. Only when this is possible is there a good chance that ongoing decision systems operating under the unanimity rule might be able to avoid the 'joint-decision trap'.

The emergence of such common orientations may be rooted in genuine altruism - a human motive whose possibility is certainly not ruled out by methodological individualism (Sen 1970; Elster 1979, p. 141) but which, nevertheless, is unlikely to play much of a role in interactions among governments, rather than among individuals. More pertinent may be the perception of a common 'identity' defined in terms of an ethnic or cultural homogeneity or a 'community of fate' derived from shared perceptions of a common history, of a common 'manifest destiny' (or common ideological goals), or of a common vulnerability. As Peter Katzenstein $(1984,1985)$ has pointed out, it is the latter characteristic which helps to explain the greater ability to achieve policy consensus of the smaller European states, as compared to the larger ones. And it is worth emphasizing that the perception of a common vulnerability may be derived not only from the exposure to external military or economic threats, but also from the living memory of fratricidal internal conflicts, as in the cases of Austria and Finland - which may also explain the rapid evolution of neo-corporatist arrangements in post-Franco Spain (PérezDiaz 1985).

Unfortunately, neither German federalism nor the European Community have been able to profit much from such perceptions of common identity or common fate during the last decade or so. In Germany, the post-war ideology of 'social partnership' is eroding under the impact of the world-wide recession (Vobruba 1983) and party-political confrontation during the period of the Social-Liberal coalition did reinforce ideological divisions in the political arena. Europe, on the other hand, has certainly profited from the traumatic memories of two world wars. But once the European Defence Community had failed, the overriding problems of common European vulnerability, protection against Germany and protection against the Soviet Union, were institutionally entrusted to NATO (and substantively to the United States), rather than to the Community. In most other regards, of course, the present European condition is one which tends to emphasize historic, ethnic, cultural, ideological and economic diversity, rather than identity, at least when compared to the smaller European states which, in some cases, are doing very 
well under the near-unanimity rules of consociational democracies (Lehmbruch 1967; Lijphart 1975; Katzenstein 1984).

The question is, therefore, whether 'problem solving' does have any chance at all in joint-decision systems which do not have the benefit of a traditional sense of common identity or an overriding perception of common vulnerability? There is a certain parallel here to early sociological discussions of Gemeinschaft and Gesellschaft, and to the pessimistic hypothesis, entertained by Tönnies (1963) and Freyer $(1964$, p. 182), of an unidirectional erosion of the traditional motivational resources of Gemeinschaft. But, of course, at the interpersonal level, Gemeinschaften are newly created all the time, and the same is true in modern industries, where they have been rediscovered under the new label of 'clans' or the old one of 'communities' (Ouchi 1980; Streeck and Schmitter 1984; Hollingsworth and Lindberg 1985). But it is also true that the evolution of 'communal' or 'solidaristic' norms among egotistic actors (who are not part of a traditional community, or shocked into solidarity by the awareness of their fatal vulnerability to internal conflict) must be a fragile process which is easily reversed.

This is true even under the best of circumstances, when the non-negative-sum character of the common enterprise is fully recognized by all participants. The willingness to accept unilateral sacrifices, on the understanding that they will not be exploited but reciprocated by others when the occasion arises, presupposes a high degree of mutual trust. If that is not yet established, but needs to be built into the process itself, the most fatal risk is bona fide disagreement over the purpose and direction of the common enterprise, which is easily misinterpreted as defection from the common endeavour. When that happens, any unilateral retaliation is likely to provoke more suspicion and even harder retaliation, setting in motion that downward spiral of 'sacrilege' and 'just retribution' which Victor Pérez-Diaz (1985) found in the Basque conflict. Thus, the absence of any strong moral, ideological or idealistic commitment on all sides is almost a necessary precondition for the gradual evolution of communal norms. But in the absence of such nonegotistic commitments it is also hard to see how community interactions might rise above the calculus of individual self-interest.

The best hope of avoiding this 'double bind' exists, of course, under conditions of continuous economic growth, when the common enterprise is clearly a positivesum game from which all are profiting. And if it is possible to establish agreement on common criteria for the distribution of benefits and contributions under these benign circumstances, there is at least a chance that the agreement might hold even when the nature of the game changes to zero-sum or negative-sum.

On theoretical grounds, there is indeed reason to assume that commonly accepted 'rules of fairness' may evolve from the interaction of purely egotistical participants (Baumol 1982; Runge 1984). Similar processes of rule generation must have been going on in German federalism and in the European Community as well, or else even the limited degree of mutual accommodation and adaptation to changing circumstances, which they have in fact achieved, would have been impossible. But given the absence of a more fundamental ideological agreement on common values, purposes and strategies, one would also expect such rules to be relatively 
simple and 'obvious' in the sense defined by Schelling (1960) and, hence, quite rigid in the face of changing circumstances.

In our studies of joint decisions in German federalism, we have indeed discovered a number of such rules which all seem to follow from a common logic of conflict avoidance or conflict minimization under conditions of continuing goal dissensus (Scharpí, Reissert and Schnabel 1976, pp. 62, 218-35; 1978). The most important one, governing institutional change, will be discussed in the next section. More pertinent to the present discussion are two rules governing the distribution of federal funds among the Länder. According to the first, all Länder must be allowed to benefit equally, according to some simple and straightforward formula, such as the number of inhabitants or, perhaps, the number of registered automobiles for the allocation of road-building funds. But if equality cannot be maintained, the fall-back rule seems to require that the losers in relative terms must at least receive their past share in absolute terms.

The fall-back rule is, of course, what one would expect from individualistic bargaining, with status quo policy as the base line for everyone, while the first rule has some claims to greater dignity. In jurisprudence and philosophy, formal equality is justified as the measure of distributive justice which should be applied in the absence of more compelling criteria based upon either unequal needs or unequal contributions (Noll 1984; Rawls 1971). As it is difficult, under conditions of party-political competition, ideological heterogeneity and significant differences in size, wealth and economic conditions, for the German Länder to agree upon substantive criteria of unequal need and merit, it is perhaps not surprising that formal equality, in the form of uniform conditions and per capita formulas, prevailed in most of the joint programmes in West Germany. But the rule obviously does not explain the highly unequal allocation of contributions and benefits among the member countries of the European Community, or in German regional assistance.

In both cases there was, at least originally, a rough agreement on the recognition of unequal needs and deserts which, in the EC, was presumably based upon the perception of a fundamental asymmetry of interests between West Germany and the rest of the Community. If the Germans were seen as the major beneficiaries of a common market for industrial goods, it was only fair that they should bear the major burden of EC financial contributions, and that they should benefit less from Community programmes. A slightly different justification could point out that the Community lacks the mechanism of horizontal transfer payments which were used to reduce fiscal inequalities among the German Länder long before the invention of joint programmes (Franzmeyer and Seidel 1976). Some EC programmes, such as the Regional Fund and the Social Fund, should thus be regarded as functional equivalents to fiscal equalization (Reissert 1979) which, of course, would preclude reference to formal equality as the relevant criterion of justice.

When the same contribution rules were applied to the United Kingdom, however (or now to Portugal), they had distributive consequences which certainly the British did not consider fair. Yet, under the unanimity requirement, the Community was unable to agree on new rules which would have redefined the criterion of fairness 
in the light of the new situation. Instead, the decision style changed from a search for just solutions to 'bloody-minded' bargaining and even confrontation, and it took the combined threats of British exit and of the bankruptcy of CAP to achieve even the ad hoc adjustments of 1984. Apparently, rules of fairness that depart from formal equality are less 'obvious' in the sense defined by Schelling (1960) and, therefore, more difficult to redefine consensually in the face of changing circumstances. If they are challenged, the joint-decision system is more likely to revert to the calculus of pure individual self-interest than to adjust its standards of fairness.

This does not mean that consensus is now impossible, and that joint-decision systems will necessarily destroy themselves through self-blockage. In an ongoing system without exit, and with 'pre-emption', pressures to reach some kind of agreement are very powerful, indeed (Weiler 1982, p. 49). But the terms of agreement are likely to be defined by a 'bargaining' logic in which the benefits received under the present policy become the base line below which nobody will settle. In the case of regional assistance in Germany, additional federal funds were required for add-on programmes dealing with the new problems of declining industrial areas. In the absence of a federal government with independent resources, or of an 'hegemony' that could be exploited (Olson and Zeckhauser 1966), 'log rolling', 'package deals' and 'side payments' are the typical modes of conflict resolution in decision systems confronted with a plurality of veto positions (Taylor 1980).

Given the claims to a substantive 'intelligence of democracy' associated with seemingly similar patterns of bargaining in American pluralism (Lindblom 1965; Dahl 1967), it is perhaps necessary to spell out more precisely what I consider the deficiencies of 'bargaining' in joint-decision systems. They are not primarily related to the difference between 'disjointed incrementalism' and an over-ambitious concept of 'synoptic problem solving' (Braybrooke and Lindblom 1963). What is important, instead, is whether analyses (and disagreements) relating to the best way of achieving common goals can, or cannot, be effectively separated from disagreement over the individual distribution of costs and benefits. If members distrust the fairness of distribution rules, they will be tempted, or even forced, to link substantive and distributive issues. Using their veto on substantive choices in order to improve their distributive position, they must contribute to the interminable haggling over package deals and side payments that are characteristic of all EC decisions. But, of course, distributive issues are legitimate even in a Gemeinschaft, and if they cannot be neutralized by agreed-upon rules of fairness, they must somehow be settled in negotiations.

There are, however, many decision situations in which adequate compensation is impossible - either because the losses involved would be of a non-quantifiable, qualitative nature, or because of uncertainty over their future incidence and magnitude, or finally because of the negative-sum character of the decision situation itself. The first case is of considerable importance not only under conditions of ideological disagreement, but even more so when considerations of national 'sovereignty', or Länder 'autonomy', or interference with established bureaucratic routines and networks of interaction, come to play a significant role. It is under 
such conditions that the imperatives of 'conflict avoidance' and 'non intervention' have their strongest impact upon the substance of joint decisions in Germany, and the same mechanisms seem to restrict the directive effectiveness of Community policies and of their implementation (Laffan 1983). The second case seems to be particularly damaging under conditions, labelled the 'interdependence trap' by Paul Taylor (1980, p. 374), when the costs of an advantageous policy proposal are well defined and certain, while the benefits are more diffuse and uncertain. In the third case, finally, the negative-sum character of the overall situation may not be generally appreciated while participants are bargaining over the avoidance of individual losses. It is plausible that these difficulties became more acute when the world economic environment changed from benign to hostile in the 1970s (Ziebura 1982).

In all three cases, however, the outcome is similar: Individual losses expected from a policy option which would be collectively optimal, cannot be adequately compensated through side payments. Under such conditions, therefore, 'bargaining' is likely to lead to solutions which are unable to achieve realizable common gains or to prevent avoidable common losses.

To summarize a perhaps overly involved line of argument, unanimity is a decision rule which can claim welfare-theoretic optimality, most plausibly, for single-shot decisions. In ongoing joint-decision systems, from which exit is precluded or very costly, non-agreement would imply the self-defeating continuation of past policies in the face of a changing policy environment. Thus, pressures to reach agreement will be great. The substance of agreement will be affected, however, by the prevailing style of decision-making. In its ability to achieve effective responses to a changing policy environment, the 'bargaining' style is clearly inferior to the 'problem-solving' style. But the preconditions of 'problem-solving' - the orientation towards common goals, values and norms - are difficult to create, and they are easily eroded in cases of ideological conflict, mutual distrust or disagreement over the fairness of distribution rules. Thus, reversion to a bargaining' style of decision making was characteristic of German federalism during the 1970s, and it seems to have been characteristic of the European Community ever since the great confrontations of the mid-1960s. The price to be paid is not simply a prevalence of distributive conflicts complicating all substantive decisions, but a systematic tendency towards sub-optimal substantive solutions. In short, it is the combination of the unanimity rule and a bargaining style which explains the pathologies of public policy associated with joint decisions in Germany and in Europe.

\section{JOINT DECISIONS AND THE DYNAMICS OF EUROPEAN INTEGRATION}

At this point, we can return to the concerns raised in the introduction. Why is it that real developments since the mid-1960s - the frustration without disintegration and resilience without progress - have disappointed hopes for a dynamic deepening and widening of European integration and invalidated predictions of an inevitable return to the intergovernmental relations of sovereign nation states? An explanation has been derived from the decision logic inherent in the particular institutional arrangements of the European community. Relating these findings to 
both the optimistic and pessimistic prognoses of the future course of European integration, the following conclusions appear to be warranted.

First, the early optimism of neo-functional integration theorists was based upon the expectation that a 'new political community, superimposed over the pre-existing ones' would emerge through the gradual shifting of the loyalties, expectations and activities of political elites toward the new European arena (Haas 1958, p. 16). The basic mechanism driving the process of political integration was identified by Ernst Haas in the concept of 'spill over' which, essentially, meant that narrowly defined European decision functions would have lateral effects on other interests which, in turn, would redirect their demands, expectations and, eventually, loyalties to the European political process. As a consequence, the support for European integration among interest groups and political parties would grow, and governments would realize that further sabotage or evasions were politically unprofitable. Hence, the powers of European institutions would be enlarged, with the consequence of further spill overs eventually bringing about a genuine political community and the acceptance of a full-fledged federal authority (Haas 1958, pp. XXXIII/IV, 3-31, 283-317).

While later interpretations by neo-functionalists, including Ernst Haas himself, have been more cautious, differentiating and, ultimately, even agnostic in their predictions (Haas 1964; 1971; Haas and Schmitter 1964; Lindberg 1963; Lindberg and Scheingold 1970; Schmitter 1969; 1970; Scheingold 1970), they have continued to place their primary emphasis upon the interaction between European decisions and the interests, expectations, activities and loyalties of interest groups, political parties, politicians and bureaucrats, in short: upon the perspectives and actions of a plurality of political elites, rather than upon the institutional self-interests of national governments operating within the constraints of particular institutional arrangements at the European level (Bulmer 1983, p. 353). As William Wallace (1982, p. 64-5) has put it: The success of the neo-functional approach depended upon national governments not noticing - in effect - the gradual draining away of their lifeblood to Brussels.'

The tendency to treat institutional arrangements not as a powerful independent variable, but merely as the resultant of economic, social and political interactions, was even more characteristic of the older, 'functionalist' school of international organization, as illustrated by David Mitrany's dictum $(1975$, p. 27) that in the last resort, the form of government and its laws and institutions are shaped and reshaped by the restless flux of the community's social pressures.' And the same non-institutional perspective is, of course also characteristic of the 'communications' approach to political integration developed by Karl Deutsch (1953) and his collaborators (Deutsch et al. 1957; 1964; Merrit and Russett 1981).

The re-emergence of 'inter-governmentalism' in the European Community after 1966 (Wallace, Wallace and Webb 1977, pp. 24-5; Taylor 1983, pp. 60-92) came as a disappointment to all such theories of political integration, giving rise to several varieties of ad hoc explanations emphasizing either changes in background' variables external to the theory, or the historical uniqueness of DeGaulle and his personal intervention. By contrast, and with the benefit of 
hindsight, my explanations assume explicitly that 'institutions do matter'.

Given this premise, the two most powerful institutional conditions affecting the processes of European integration are, first, the fact that national governments are making European decisions and, second, the fact that these decisions have to be unanimous. The 'joint-decision trap' set up by these two conditions is responsible for the pathologies of substantive public policy described and analysed above.

But joint-decision systems are a 'trap' in yet another, and more important sense. They are able to block their own further institutional evolution. This possibility has been overlooked by functionalist and neo-functionalist writers, and even William Riker, the most agnostic student of federalism (1966), had assumed that in any federal arrangement one of two tendencies, 'centralizing' or 'peripheralizing', must eventually win out $(1964$, p. 6), with the 'structure of the party system' as the controlling variable (1964, pp. 129-36). While peripheralized federalisms will gradually fall apart, centralized federalisms will become more like unitary or imperial governments in time' (1964, p. 7). But neither outcome is happening in either the EC or Germany. The institutional arrangements of German federalism are quite stable, and the European Community seems to be securely 'stuck between sovereignty and integration' (Wallace 1982, p. 67). Our studies of joint decisions in German federalism have discovered a mechanism that preserves the institutional status quo: it is the political priority of substantive solutions over institutional reforms.

All through the 1970s, the German federal government was confronted with urgent problems of unemployment and inflation that seemed to require vigorous action at the national level which, however, depended upon the collaboration of the Länder. Even though the majority of the Bundesrat consisted of Länder governments controlled by parties in opposition to the Social-Liberal federal government, collaboration was never flatly refused. If that had been the case, the legitimacy of the veto position of the Bundesrat could have become a major political issue which might have strengthened centralist forces. As it was, the Länder were always willing to compromise on substantive policy, and the federal government was too hard pressed politically to refuse the compromises which were offered. In the process, however, the institutional position of the Länder was continuously improved. Fiscal resources were shifted from the federal level to the Länder, precisely during the decade when the federal government was more activist and interventionist than ever before. During the same period, the Länder have time and again consented to enlarge the substantive responsibilities of the federal government, but they have also increased their own control over the exercise of these responsibilities. In order to avoid this gradual erosion of its institutional position, the federal government would have had to provoke the direct confrontation of the Länder over institutional issues. But under the pressure of urgent substantive problems, it was never willing to risk the complete blockage of joint-decision processes in the (uncertain) hope of improving its position in the longer run. Acting as a locally maximizing machine' (Elster 1979, p. 4), the federal government contributed to the tightening of the ropes that reduced its own ability to act.

The situation is even more one-sided in the European Community. In the absence 
of a European government with a popular political base of its own, all possibilities of institutional transformation are entirely determined by the self-interests of national governments. And even those among them which most vigorously support activist and expansionary European policies are likely to hedge their bets when it comes to relinquishing their veto powers. Conversely, the 'reluctant Europeans' among member governments have been much more willing to accept disagreeable compromises on substantive policy than to weaken their own institutional control over the substance of future decisions. As a consequence, the jurisdiction of the Community has expanded, and Community law has achieved the effectiveness of the legal order of a federal state - but the price has been 'an ever closer national control exercised in the decision processes' (Weiler 1982, pp. 46-7).

Thus, the establishment of the European Council should be interpreted as a symbol of the increasing importance of European policy choices and as an attempt to assert the control of national policy generalists over the vertical alliances of policy specialists dominating the Council of Ministers as well as the European Commission. But that only means that it is national heads of government, rather than national ministers, who are likely to tighten their grip in European policy making (Bulmer, 1983). Nor are these conclusions controverted by the packages of compromises and reforms culminating in the 'Single European Act' of 28 February 1986 which seems to have ended the long period of confrontations and deadlock of the 1970s and early 1980s. Spain and Portugal were finally admitted and interim settlements for the budget issues were found. Even more spectacularly, governments committed themselves to complete the 'internal market' - 'an area without internal frontiers in which the free movement of goods, persons, services and capital is assured' - by the end of 1992 (article 13), and they also renewed their aspirations toward an 'Economic and Monetary Union' requiring the convergence of national economic and monetary policies (article 20).

Compared to these substantive commitments, whose implementation continues to depend upon the agreement of national governments, the institutional changes which were adopted seem to fall far short of the visionary goals of achieving 'genuine political unity' through the creation of 'effective democratic institutions' that had been asserted only a year before (Report of the Dooge Committee 1984). To be sure, on a long list of routine decisions, qualified-majority voting in the Council (which always would have been possible) is now explicitly provided for in the Treaty - and it is apparently practised quite frequently, with governments preferring to be outvoted, rather than having to agree formally to an inevitable but unpopular Council decision. It remains to be seen whether the weakening of the pressures toward consensus will be outweighed by the lower threshold of agreement. At any rate, a long list of more important decisions, and all further evolutions of the Treaty structure, are explicitly reserved for unanimous voting, and the general principle under which all members may exercise a veto in matters affecting their vital national interests remains unchallenged. Ironically, the very limited efforts to strengthen the powers of the European Parliament not only have taken the form of adding another institutional hurdle to European decision making, but have reinforced the practical significance of unanimity within the Council 
(where it is necessary to override objections or amendments of the Parliament).

On the basis of German experience, one would expect that even the formal relaxation of the unanimity rule may not make much of a difference in practice. As long as it is still national governments that are making European decisions, their common interest in preserving their institutional veto is likely to prevail as well (Everling 1980). In that regard, all neo-functionalist hopes that learning processes would lead to an institutional transformation seem to have been misplaced. The 'transformation group' (Piaget 1973, p. 14; Deutsch 1977, p. 23) of a joint-decision system does not seem to include the self-transformation into a simpler system based upon binding majority decisions. Or, as Helmut Schmidt once remarked with a view to German federalism: 'Any attempt to reform a complex constitution can only increase its complexity.'

If that is so, two of the crucial spill-over mechanisms, which neo-functionalist theory expected to create external political pressures for more integration, seem to be blocked or seriously weakened. First, the reorientation of economic, social and political interests toward the European level remains incomplete. As long as European decisions continue to be made by national governments, the interests affected by them will be mediated by national governments as well. Of course, interest groups will also operate at the European level, but ultimately it is still national governments which they will have to persuade. As a consequence, nationally specific definitions of group interests, and of party-political ideologies, will be maintained and reinforced, rather than amalgamated into European interest associations (Averyt 1976) and European political parties. In that regard, the tendencies toward the segregation of interests and ideologies inherent in federal, as compared to unitary, states are even more pronounced among the member states of the Community (Kirsch 1984, p. 122). By the same token, there is less reason to expect a transfer of the demands, expectations and loyalties of political elites from the national to the European level.

Second, there is much less reason to expect that 'goal frustration' should lead to 'politicization' and, ultimately, to a redefinition of goals and the 'transcendence' to a higher level of political integration (Schmitter 1969, p. 164). If the iron grip of national governments cannot be broken, the decision logic of European institutions will continue to reproduce the substantive pathologies discussed above. Beyond a certain point, surely, political frustration and exasperation over the inefficiency and inflexibility of European policy making, and over its structural inability to respond to crises creatively, may not lead to renewed demands for 'a more perfect union' but, rather, to cynicism and indifference or to a renewed search for national remedies, however imperfect and limited, for the problems which the Community seems to handle so poorly. As was the case with joint policies in West Germany, the dynamic movement toward greater European integration may have been retarded and, perhaps, reversed, not by the ideological strength of nationalism or by the obstructions of a Charles DeGaulle or a Margaret Thatcher, but by the pathological decision logic inherent in its basic institutional arrangements.

But why is it, then, that the Community didn't disintegrate long ago? As in the case of German federalism, an adequate explanation of its continuing resilience 
needs to consider two levels of interest, functional and institutional. At the functional level, it is clear that at least some of the benefits predicted by the economic theories of integration have in fact been realized. This tends to be more true for the benefits of 'market integration' than of 'policy integration' (Pelkmans 1980) or of 'negative', rather than 'positive', integration (Taylor 1980, pp. 384-5). But as it is uncertain, even in the industrial sector, whether the common market could be maintained in the absence of a substantial commitment to common (and compensatory) policy measures in such areas as the Social Fund, the Regional Fund and Industrial Policy, one probably could not have the one without the other. In other words, to the extent that joint policies are addressing, however inadequately, real problems which could not be handled at the level of member governments, these problems would simply reassert themselves if the joint-policy system were to be dismantled.

The functional argument is not controverted by the fact that not all economicpolicy problems can be handled at the Community level (Ziebura 1982), or that some of the smaller European countries outside of the Community (Switzerland, Austria, Finland, Sweden and Norway) have, on the whole, done better during the world-wide recession of the 1970s than similar countries within the Community (Denmark, the Netherlands, Belgium and Ireland). As all of the successful outsiders are dependent upon industrial exports to the Community, they may simply have been free riders profiting from the creation of the common market and from the Community's relatively liberal trade policies in the industrial sector. Exporters of agricultural goods, on the other hand, like Denmark, Ireland, Greece, Spain and Portugal, had every incentive to join the Community in order to evade CAP's prohibitively high protective barriers. Thus, the appeal of economic integration remains alive, and it is even reinforced, at least for the European Left, by the realization that the internationalization of capital markets has destroyed any hopes for Keynesian full employment policies at the national level (Pelkmanns 1980, pp. 344-5; Scharpf 1987, chs. 11-12). Unfortunately, if my understanding of the jointdecision trap' is correct, hopes for an effective 'European Keynesianism' are likely to be futile as well.

At the institutional level, the Community is unequivocally supported by the self-interest of the vertical alliances of policy specialists - interest associations, national ministries and parliamentary committees, and the large contingents of specialized lobbyists, bureaucrats and politicians operating at the European level. They all profit from the availability of additional resources, and of additional points of access to political decision processes, providing additional opportunities for playing the game of influence and obstruction which is their raison d'être. Of course, they also must cope with the political frustration, among their clienteles or electorates, over the impact of sub-optimal or even counter-productive European policies. But, as in German federalism, the political effect of voter frustration is largely neutralized by the very diffusion of responsibility and accountability which is characteristic of joint-decision systems (Scharpf, Reissert and Schnabel 1976, p. 236).

Similar cost-benefit calculations tend to stabilize the Community from the 
perspective of national policy generalists - heads of government, finance ministers and parliamentary budget committees - if their countries are among the net beneficiaries of the Community budget. Net contributors, on the other hand, find themselves locked into an ongoing decision system whose direction they could only hope to change significantly by either assuming the burdens and costs of hegemonic leadership or by threatening to leave the Community altogether. As it is, the only pretender to hegemonic status, West Germany, is too weak or too egoistical to assume the burdens of leadership, while confrontation strategies are unlikely to work for countries whose interest in, and attachment to, the Community is known to be very great. Thus, the Community is likely to remain secure as long as care is taken to concentrate net contributions to the Community budget upon those countries which would have most to lose economically and politically by its dissolution and, in particular, by the disintegration of the common market.

By way of summary, it is now possible to define the 'joint-decision trap' more precisely. It is an institutional arrangement whose policy outcomes have an inherent (non-accidental) tendency to be sub-optimal - certainly when compared to the policy potential of unitary governments of similar size and resources. Nevertheless, the arrangement represents a 'local optimum' in the cost-benefit calculations of all participants that might have the power to change it. If that is so, there is no 'gradualist' way in which joint-decision systems might transform themselves into an institutional arrangement of greater policy potential. In order to be effective, institutional change would have to be large-scale, implying the acceptance of shortterm losses for many, or all, participants. That is unlikely, but not impossible (Elster 1979). And, of course, the system might be jolted out of its present equilibrium by external intervention or by a dramatic deterioration of its performance which would undermine even its 'local optimality' for crucial participants. Thus, I have not described a deterministic world, even though the logic of the 'joint-decision trap' may provide as close an approximation to structural determinism as one is likely to encounter in the social sciences.

\section{SOME TENTATIVE EXTENSIONS}

Our analyses of 'Politikverflechtung' pose the question of whether or not the findings can be generalized. We tended to emphasize the specificity of the historical case from which the conclusions were derived (Scharpf 1978a) but nevertheless we attempted to formulate the findings in the language of universalistic propositions. The present essay claims that these propositions also help to explain the European experience. In effect, these cases may be instances of a universal decision logic inherent in particular 'patterns', in the sense discussed by von Hayek (1967), of institutional arrangements. This conclusion offers a few speculative suggestions about other areas of potential application.

Clearly, the 'joint-decision trap' is not inherent in all forms of de facto unanimous decision making, even if we exclude (as one should) single-shot encounters. By the same logic, one should probably also exclude all forms of ongoing associations from which exit is very easy, either because their benefits are of marginal 
value to members, or because they could easily be substituted from another source. Furthermore, it seems also appropriate to exclude associations in which the tension between common and individual interests could not arise because member interests are complementary, and costs low in comparison to the benefits of associaton. Cliques, clubs and business consortia might fall into that class. More doubtful candidates for either inclusion or exclusion are organizations with member interests that are partly complementary and partly competitive, but where members are not expecting each other to pursue anything but their own, individual self-interest. Many forms of long-standing vertical relationships between suppliers and customers fall into that category, but also horizontal cartels and 'free collective bargaining' between employers and trade unions. I would also include here the 'co-operation among egoists' in long sequences of the Prisoners' Dilemma and similar real-world situations. In my view, cases in this category would not provide valid tests for the 'joint-decision trap' hypothesis. While an outside observer might perceive potential 'common' interests and, hence, benefits from 'problem solving', participants may have good reasons to define their mutual relations purely in 'bargaining' terms. Being where they want to be, they are not in any meaningful sense in a 'trap'.

But even if we limit the discussion to ongoing joint-decision systems without exit, in which 'common' interests have a normative validity that is separate from, but not necessarily superior to, the individual self-interest of participants, and in which 'problem solving' would be the more efficient style of decision making, we would still cast the net too wide. 'Problem solving' is, after all, a style of decision making that is frequently encountered in decision situations which are formally operating under hierarchical or majority decisions rules, even though there may be de facto unanimity for most practical purposes. Indeed, that may be the secret of their success: 'participative management' (as distinguished from 'laissez-faire management') is likely to profit from the creativity and intelligence of employees precisely because disintegrative tendencies are held in check by a hierarchical authority that has abdicated some, but not all, of its functions. Conversely, formally egalitarian decision situations might profit from the de facto hierarchical role of one hegemonic member - as exemplified by the powerfully integrative role of . Prussia in Bismarck's Germany. Similarly, one might suspect that 'consociational democracies' and even American-style 'pluralism' would not work quite as well if obstinate minorities did not have to reckon with the possibility that the formal rule of majority decision might still be invoked against them. The precarious stability of 'problem solving', and the tendency to revert to the 'bargaining' style is, thus, likely to manifest itself most clearly in joint-decision systems in which de facto unanimity is not backed up by the formal possibility of unilateral or majority decisions or by the clear preponderance of power of a hegemonic member.

Even within these definitional constraints, however, there seems to be a wide range of institutions to which the logic of the "joint-decision trap' might plausibly apply. Faculty self-government (in the absence of a powerful president or dean) might be one example. Legalized communes of squatters in West Berlin (tied to their houses by the sunk costs of rebuilding them) could be another. Further candidates could be connubia, business partnerships and joint ventures, political 
coalitions, military alliances, 'neo-corporatist' arrangements and a wide variety of permanent inter-organizational networks. They are all likely to be confronted with tensions between a recognized common interest and the individual self-interest of participants; they all would profit from a 'problem-solving' style of decision making, if only distributive conflicts could, somehow, be neutralized; and they all should be exposed to the entropic push toward 'bargaining'. At the same time, they all should have difficulties in adopting a decision rule (majority or hierarchy) that could avoid reversion to the bargaining style at the expense of membership control over the substance of decisions.

Thus, it should be possible to test the 'joint-decision-trap' hypothesis under an extremely wide variety of institutional conditions. More interesting, from my point of view, would be the opportunity provided by such empirical studies to identify more precisely those factors that are able to influence the changes of decision styles, from 'bargaining' to 'problem solving' and vice versa, in joint-decision systems. Given an increasingly interdependent world, all mechanisms and strategies that might help to avoid the 'joint-decision trap' ought to be of very considerable scholarly and practical interest.

\section{REFERENCES}

Abromeit, Heidrun. 1982. Die Funktion des Bundesrats und der Streit um seine Politisierung', Zeitschrift für Parlamentsfragen 13, 462-72.

Averyt, William F. jr. 1976. Agricultural interest groups in the European Community: the Commité des Organisations Professionelles Agricoles. Ph.D. Yale University, May.

Axelrod, Robert. 1981. The emergence of cooperation among egoists', American Political Science Review 75, 306-18.

Axelrod, Robert. 1984. The evolution of cooperation. New York: Basic Books.

Bacharach, S. B. and E. J. Lawler. 1980. Power and politics in organizations. London: Jossey-Bass.

Balassa, Bela. 1962. The theory of economic integration. London: George Allen and Unwin.

Balz, M., R. Meimberg and M. Schöpe. 1982. 'Agrarstrukturpolitik in der EG - Regionale Entwicklungsstrategien erforderlich', Ifo Schnelldienst 32/82, 10-20.

Baumol, William J. 1982. 'Applied fairness theory and rationing policy', American Economic Review September, 639-51.

Bentele, Karlheinz. 1979. Kartellbildung in der allgemeinen Forschungsförderung. Königstein: Anton Hain.

Benz, Arthur. 1985. Föderalismus als dynamisches System. Opladen: Westdeutscher Verlag.

BMBW. 1982. Informationen/Bildung/Wissenschaft des Bundesministers für Bildung und Wissenschaft. Nr. 4/82. Bonn: 22 April.

BMF. 1985. Bundesministerium der Finanzen. Die finanzwirtschaftliche Entwicklung von Bund, Ländern und Gemeinden seit 1970. Dokumentation 2/85. Bonn: 31 January 1985.

BMF. 1982. Bundesministerium der Finanzen. Die Finanzbeziehungen zwischen Bund, Ländern und Gemeinden aus finanzverfassungsrechtlicher und finanzwirtschaftlicher Sicht. Bonn.

Body, Richard. 1982. Agriculture: the triumph and the shame. London: Temple Smith.

Bonoma, Thomas V. 1976. 'Conflict, cooperation and trust in three power systems', Behavioral Science 21, 499-514.

Borell, R. 1981. Mischfinanzierungen. Darstellung, Kritik, Reformüberlegungen. Wiesbaden: KarlBräuer-Institut.

Braybrooke, David and Charles E. Lindblom. 1963. A strategy of decision. Policy evaluation as a social process. New York: The Free Press.

Breton, Albert and Anthony Scott. 1978. The economic constitution of federal states. Toronto: University of Toronto Press.

Bruder, Wolfgang. 1983. The regional policy of the European Community: problems and perspectives. Ms. Universität Konstanz.

Buchanan, James M. and Gordon Tullock. 1962. The calculus of consent. Logical foundations of constitutional democracy. Ann Arbor, Michigan: University of Michigan Press. 
Buchanan, James M. 1975. The limits of liberty. Between anarchy and Leviathan. Chicago: University of Chicago Press.

Bühl, Walter L. 1984. 'Die Dynamik sozialer Konflikte in katastrophentheoretischer Darstellung', Kölner Zeitschrift für Soziologie und Sozialpsychologie, 641-66.

Bulletin der Europäischen Gemeinschaften. Nr. 11, 1984.

Bulmer, Simon. 1983. Domestic politics and European Community policy making', Joumal of Common Market Studies 21, 349-63.

BVerfGE. 1975. Entscheidungen des Bundesverfassungsgerichts. Band 39.

Dahl, Robert H. 1967. Pluralist democracy in the United States: conflict and consent. Chicago: Rand McNally.

Dawkins, Richard. 1976. The selfish gene. Oxford: Oxford University Press.

Deutsch, Karl. 1953. Nationalism and social communication: an inquiry into the foundations of nationality. Cambridge, Mass.: MIT Press.

Deutsch, Karl (with S. A. Burell, R. A. Kann, M. Lee, M. Lichtermann and R. W. van Wagenen). 1957. Political community and the North Atlantic area. Princeton: Princeton University Press.

Deutsch, Karl (with P. E. Jacob, H. Teune, J. V. Toscano and W. L. C. Wheaton). 1964. The integration of political communities. Philadelphia: Lippincott.

Deutsch, Karl. 1977. National integration. Some concepts and research approaches', Jerusalem Joumal of Intemational Relations 2, 1-29.

DIW. 1984. Deutsches Institut für Wirtschaftsforschung. EG-Haushalt und -Agrarpolitik. DIW Wochenbericht 40/84, 497-501.

DIW. 1984a. Deutsches Institut für Wirtschaftsforschung. Statt Subventionsabbau neue Hilfen für die Landwirtschaft. DIW Wochenbericht 25/84, 297-302.

Downs, Anthony. 1957. An economic theory of democracy. New York: Harper and Row.

Dunsire, A. 1978. Implementation in a bureaucracy. Oxford: Martin Robertson.

Easton, David. 1965. A systems analysis of political life. New York: John Wiley.

Elster, Jon. 1979. Ulysses and the Sirens. Studies of rationality and irrationality. Cambridge: Cambridge University Press.

Everling, Ulrich. 1980. 'Possibilities and limits of European integration', Journal of Common Market Studies 18, 217-28.

Fabritius, Georg. 1978. Wechselwirkungen zwischen Landtagswahlen und Bundespolitik. Meisenheim: Anton Hain.

Feld, Werner J. 1980. 'Two-tier policy making in the EC: the Common Agricultural Policy', in Leon Hurwitz (ed.), Contemporary perspectives on European integration. London: Aldwich Press.

Franzmeyer, Fritz and Bernhard Seidel. 1976. Überstaaticher Finanzausgleich und Europäische Integration. Bonn: Europa Union Verlag.

Frey, Bruno S. 1977. Modeme Politische Ökonomie. München: Piper.

Freyer, Hans. 1964. Soziologie als Wirklichkeitswissenschaft. Stuttgart: Teubner (First Edition 1930).

Garlichs, Dietrich. 1980. Grenzen staatlicher Infrastrukturpolitik. Bund/Länder-Kooperation in der Fernstraßenplanung. Königstein: Anton Hain.

v. d. Groeben, Hans and Ernst-Joachim Mestmäcker. (Hrsg.). 1974. Verfassung oder Technokratie für Europa. Frankfurt/M.: Athenäum Fischer.

Haas, Ernst B. 1958. The uniting of Europe. Political, social and economic forces 1950-1957. London: Stevens and Sons (1968 edition by Stanford University Press).

- 1964. Beyond the nation state. Functionalism and intemational organization. Stanford: Stanford University Press.

Haas, Ernst B. and Philippe C. Schmitter. 1964. 'Economics and differential patterns of political integration: projections about unity in Latin America', International Organization 18, 705-37.

Haas, Ernst B. 1971. The study of regional integration: reflections on the joy and anguish of pretheorizing, in L. N. Lindberg and S. A. Scheingold (eds.), Regional integration, theory and research. Cambridge, Mass.: Harvard University Press, 3-42.

Harrison, Reginald J. 1974. Europe in question: Theories of regional international integration. London: George Allen and Unwin.

von Hayek, F. A. 1967. The theory of complex phenomena', in F. A. von Hayek, Studies in philosophy, politics and economics. London: University of Chicago Press.

Heidenheimer, Arnold. 1958. 'Federalism and the party system - the case of West Germany', American Political Science Review. September.

Heidenheimer, Arnold J., Hugh Heclo and Carolyn Teich-Adams. 1975. Comparative public policy. New York: St. Martin's Press. 
- 1983. Comparative public policy. The politics of social choice in Europe and America. Second Edition, London: Macmillan.

Hesse, Konrad. 1962. Der unitarische Bundesstaat. Karlsruhe: Müller.

Hesse, Joachim Jens, (Hrsg.), 1978. Politikverflechtung im föderativen Staat. Baden-Baden: Nomos.

Höhne, Wilfrid and Günther Horzetzky. 1984. 'Europäische Agrarpolitik: Probleme und Reformansätze', Gewerkschaftitiche Monatshefte 35, 310-22.

Hoffman, Stanley. 1966. 'Obstinate or obsolete? the fate of the nation-state and the case of Western Europe', Daedalus Summer 1966, 862-915.

Hollingsworth, J. Rogers and Leon N. Lindberg. 1985. The government of the American economy: the role of markets, clans, hierarchies and associative behavior. MS University of Wisconsin.

Howard, Nigel. 1971. Paradoxes of rationality: theory of metagames and political behavior. Cambridge, Mass.: MIT Press.

Hrbek, Rudolf. 1979. 'Politikverflechtung macht an den Grenzen nicht halt. Auswirkungen der EGMitgliedschaft auf die föderative Ordnung der Bundesrepublik Deutschland', Der Bürger im Staat 29, Jahrgang, Heft 1, 38-43.

Hrbek, Rudolf and Wolfgang Wessels (Hrsg.). 1984. EG-Mitgliedschaft: ein vitales Interesse der Bundesrepublik Deutschland? Bonn: Europa Union Verlag.

Johnson, Nevil. 1973. Government in the Federal Republic of Germany. The executive at work. Oxford: Pergamon Press.

Jürgensen, Stephan and Schmitz, Peter M. 1984. 'EG Agrarpolitik: Der Streit um den Grenzausgleich', Wirtschaftsdienst IV/84, 192-6.

Katzenstein, Peter. 1984. Corporatism and change. Austria, Switzerland and the politics of industry. Ithaca: Cornell University Press.

- 1985. Small nations as experiments? Experiences from Europe (and other places). MS Ithaca, February.

Kirsch, Guy (Hrsg.). 1977. Föderalismus. Stuttgart: Gustav Fischer.

Kirsch, Guy. 1984. 'Fiscal federalism', Wirtschaftswissenschaftliches Studium, März, 118.

Klatt, Hartmut. 1979. 'Die Länderparlamente müssen sich wehren. Möglichkeiten und Ansätze einer Reform des Länderparlamentarismus', Der Bürger im Staat 21, Heft 1, 1979, $20-8$.

Knott, Jack H. 1981. Managing the German economy. Budgetary politics in a federal state. Lexington, Mass.: Lexington Books.

Kohr, Leopold. 1978. The breakdown of nations. New York: Dutton.

Kommission für die Finanzreform. 1966. Gutachten über die Finanzreform in der Bundesrepublik Deutschland. Stuttgart: Kohlhammer.

Laffan, Brigid. 1983. 'Policy implementation in the European Community: the European Social Fund as a case study', Journal of Common Market Studies 21, 389-408.

Lehmbruch, Gerhard. 1967. Proporzdemokratie: Politisches System und politische Kultur in der Schweiz und Österreich. Tübingen: J. C. B. Mohr.

-. 1976. Parteienwettbewerb im Bundesstaat. Stuttgart: Kohlhammer.

Lehner, Franz. 1979. 'Politikverflechtung: Institutionelle Eigendynamik und politische Kontrolle' in Joachim Matthes (Hrsg.), Soziuler Wandel in Westeuropa. Verhandlungen des 19. Deutschen Soziologentages. Frankfurt: Campus, 611-25.

-. 1979a. 'Politikverflechtung - Föderalismus ohne Transparenz', Der Bürger im Staat 129, Heft 1, 3-8.

Lijphart, Arend. 1975. The politics of accommodation. Pluralism and democracy in the Netherlands. Second Edition, Berkeley: University of California Press.

Lindberg, Leon N. 1963. The political dynamics of European integration. Stanford: Stanford University Press.

Lindberg, Leon N. and Stuart A. Scheingold. 1970. Europe's would-be polity. Patterns of change in the European Community. Englewood Cliffs: Prentice-Hall.

Lindblom, Charles E. 1965. The intelligence of democracy. New York: The Free Press.

March, James G. and Herbert A. Simon. 1958. Organizations. New York: John Wiley.

Martins, Mario R. and John Mawson. 1982. The programming of regional development in the EC: Supra-national or international decision-making?' Joumal of Common Market Studies 20, 229-44.

Merrit, Richard L. and Bruce C. Russett. (eds.). 1981. From national development to global community. London: George Allen and Unwin.

Mitrany, David. 1975. 'A political theory for the new society', in: A. J. R. Groom and Paul Taylor (eds.), Functionalism. theory and practice in intemational relations. London: University of London Press, 25-37. 
Mueller, Dennis C. 1979. Public choice. Cambridge: Cambridge University Press.

Nash, John F. jr. 1950. 'The bargaining problem', Econometrica, 18, 155-162.

Niskanen, William A. 1971. Bureaucracy and representative govemment. Chicago: Aldine-Atherton.

Noé, Claus. 1983. Wo sind 19,5 Milliarden DM geblieben? Bemerkungen zu Zielen, Mitteln und Wirkungsweise regionalpolitischer Versuche der Europäischen Gemeinschaft', Raumforschung und Raumordnung, 15-20.

Nölling, Wilhelm. 1977. 'Das Programm für Zukunftsinvestitionen', Wirtschaftsdienst VIII, 391.

Noll, Peter. 1984. Diktate über Sterben und Tod. Zürich: Pendo.

Oates, Wallace E. 1972. Fiscal federalism. New York: Harcourt Brace Jovanovich.

Offe, Claus. 1975. Berufsbildungsreform. Eine Fallstudie über Reformpolitik. Frankfurt: Suhrkamp.

Olsen, Johan, Paul Roness and Harald Saetren. 1982. Norway: still peaceful coexistence and revolution in slow motion?', in Richardson, J. (ed.), Policy Styles in Western Europe. London, 47-9.

Olson, Mancur and Richard Zeckhauser. 1966. 'An Economic Theory of Alliances', Review of Economics and Statistics 48, 266-79.

Olson, Mancur. 1969. The principle of fiscal equivalence: the division of responsibilities among different levels of government', American Economic Review May Supplement, 479.

Ostrom, Elinor. 1984. Multiorganizational arrangements and coordination: an application of institutional analysis. MS. Workshop in Political Theory and Policy Analysis. Bloomington, Indiana: Indiana University.

Ostrom, Vincent. 1984. The political theory of a compound republic. Revised Edition, Bloomington, Indiana: Indiana University.

Ouchi, William G. 1980. Markets, bureaucracies and clans', Administrative Science Quarterly 25, 129-41.

Parsons, Talcott. 1967. 'Voting and the equilibrium of the American political system', in T. Parsons, Sociological theory and modem society. New York: Free Press, 223-63.

Pelkmans, Jacques. 1980. 'Economic theories of integration revisited', Joumal of Common Market Studies 18, 333-54.

Pentland, Charles. 1973. International theory and European integration. London: Faber and Faber.

Pérez-Diaz, Victor M. 1985. Governability and mesogovernments: regional autonomies and neocorporatism in Spain. MS Madrid, February 1985.

Piaget, Jean. 1973. Der Strukturalismus. Olten und Freiburg i. Br.: Walter Verlag.

Rawls, John. 1971. A theory of justice. Cambridge, Mass.: Harvard University Press.

Reissert, Bernd. 1979. 'Politikverflechtung' in der Europäischen Gemeinschaft. MS. Wissenschaftszentrum Berlin.

-. 1984. Staatliche Zuweisungen und kommunale Investitionspolitik (Politikverflechtung VI). MS. Wissenschaftszentrum Berlin.

Richardson, Jeremy (ed.). 1982. Policy styles in Westem Europe. London: George Allen and Unwin.

Riker, William H. 1962. The theory of political coalitions. New Haven: Yale University Press.

- 1964. Federalism: origin, operation, maintenance. Boston: Little Brown.

- . 1969. 'Six books in search of a subject or does federalism exist and does it matter?' Comparative Politics October, 135.

Riker, William H. 1975. 'Federalism', in F. I. Greenstein and N. W. Polsby (eds.), Governmental institutions and processes. Handbook of Political Science, Vol. 5. Redding, Mass.: Addison-Wesley, 93-172.

Rodemer, Horst. 1980. Die EG-Agrarpolitik, Ziele, Wirkungen, Altemativen. Tübingen.

Rothenberg, Jerome. 1970. 'Local decentralization and the theory of optimal government', in Julius Margolis (ed.), The analysis of public output. New York: Columbia University Press, 31-64.

Runge, Charles F. 1984. 'Institutions and the free rider: the assurance problem in collective action', Joumal of Politics 46, 154-81.

Scharpf, Fritz W. 1970. Demokratietheorie zwischen Utopie und Anpassung; Kronberg: Scriptor (Nachdruck 1975).

- 1972. 'Komplexität als Schranke der politischen Planung', Politische Vierteljahresschrift 13. Sonderheft 4, 168-92.

Scharpf, Fritz W., Bernd Reissert, and Fritz Schnabel. 1976. Politikverflechtung. Theorie und Empirie des kooperativen Föderalismus in der Bundesrepublik. Kronberg: Scriptor 1976.

Scharpf, Fritz W., Bernd Reissert, and Fritz Schnabel (Hrsg.). 1977. Politikverflechtung II. Kritik und Berichte aus der Praxis. Kronberg: Athenäum. 
Scharpf, Fritz W. 1977. 'Public organization and the waning of the welfare state', European Joumal of Political Research December, 339.

- 1978a. 'Die Theorie der Politikverflechtung: Ein kurzgefaßter Leitfaden', in Joachim Jens Hesse (Hrsg.), Politikverflechtung im föderativen Staat. Baden-Baden: Nomos.

- 1978. 'Interorganizational policy studies: issues, concepts and perspectives', in K. Hanf and F. W. Scharpf (eds.), Interorganizational policy making. Limits to coordination and central control. London: Sage, 345-70.

-. 1985. 'Beschäftigungspolitische Strategien in der Krise', Leviathan 1, 1-22.

Scharpf, Fritz W., Bernd Reissert, and Fritz Schnabel. 1978. 'Policy effectiveness and conflict avoidance in intergovernmental policy formation', in K. Hanf and F. W. Scharpf (eds.), Interorganizational Policy Making. London: Sage, 57-112.

Schelling, Thomas C. 1960. The strategy of conflict. Cambridge, Mass.: Harvard University Press.

Scheingold, Stuart A. 1970. 'Domestic and international consequences of regional integration', International Organization, 978.

Schmidt, Helmut. 1980. 'Ansprache des Bundeskanzlers in der 494. Sitzung des Bundesrates am 12.12.1980', Stenographische Berichte des Bundesrats, von der 482. bis zur 494. Sitzung, Bonn, 431-5.

Schmitter, Philippe C. 1969. 'Three neo-functional hypotheses about international integration', International Organization 23, Winter, 161-6.

-. 1970. 'A revised theory of regional integration', Intemational Organization 24, 836-68.

Schnabel, Fritz, 1980. Politischer und administrativer Vollzug des Krankenhausfinanzierungsgesetzes. MS. Wissenschaftszentrum Berlin.

Schultze, Rainer-Olaf. 1982. 'Politikverflechtung und konföderaler Föderalismus: Entwicklungslinien und Strukturprobleme im bundesrepublikanischen und kanadischen Föderalismus', Zeitschrift der Gesellschaft für Kanada-Studien 2, 113-44.

Scitovsky, Tibor. 1958. Economic theory and Westem European integration; London: George Allen and Unwin.

Sen, Amartya K. 1970. Collective choice and social welfare. Edinburgh: Oliver and Boyd.

-. 1977. 'Rational fools: a critique of the behavioral foundations of economic theory', Philosophy and Public Affairs 6, 317-44.

Sharpe, L. J. 1985. Territoriality and the European state system. MS Oxford, March.

Simmert, Diethard B. and Kurt-Dieter Wagner (Hrsg.). 1981. Staatsverschuldung kontrovers. Bonn: Bundeszentrale für Politische Bildung.

Slater, Martin. 1982. 'Political elite, popular indifference and community building', Joumal of Common Market Studies 21, 69-86.

Späth, L., E. Teufel, E. Eppler, and J. Morlock. 1979. 'Föderalismus heute. Regierung und Landtagsfraktionen nehmen Stellung', Politikverflechtung oder Föderalismus heute. Der Bürger im Staat 29, Heft 1, 52-8.

Steinle, Wolfgang J. and Karl A. Stroetmann. 1983. 'Gemeinschaftliche Forschungs- und Technologiepolitik als Beitrag zur regionalen Entwicklung Europas', Raumforschung und Raumordnung 1983, 57-62.

Streeck, Wolfgang and Philippe C. Schmitter. 1984. Community, market, state and associations: the prospective contribution of interest governments to social order. Florence: European University Institute Working Paper 94.

Strohe, Franz-Josef. 1982. 'Zusammenwirken von Bund und Ländern bei der Bildungsplanung', BMF, 1982, 561-80.

Taylor, Paul. 1980. 'Interdependence and autonomy in the European Communities: the case of the European monetary system', Journal of Common Market Studies 18, 370-87.

- 1983. The limits of European integration. London: Croom Helm.

Tönnies, Ferdinand. 1963. Gemeinschaft und Gesellschaft. Darmstadt: Wissenschaftliche Buchgesellschaft (First Edition 1887).

Trivers, Robert L. 1971. The evolution of reciprocal altruism', Quarterly Review of Biology 46, 35-57.

Tullock, Gordon. 1965. The politics of bureaucracy. Washington, D.C.: Public Affairs Press.

- 1969. 'Federalism: problems of scale', Public Choice, 19-29.

Vobruba, Georg (ed.). 1983. 'Wir sitzen alle in einem Boot'. Gemeinschaftsrhetorik in der Krise. Frankfurt.

Wallace, Helen, William Wallace, and Carole Webb (eds.). 1977. Policy making in the European communities. London: John Wiley.

Wallace, William. 1982. 'Europe as a confederation: the Community and the nation state', Joumal of Common Market Studies 21, 57-68. 
Weiler, Joseph. 1982. 'Community member states and European integration. Is the law relevant?' Joumal of Common Market Studies 21, 39-56.

Wheare, K. C. 1960. Federal government. 4th Edition, Oxford: Oxford University Press.

Ylvisaker, Paul. 1959. 'Some criteria for a "proper" areal division of governmental powers', in: Arthur Maass, (ed.), Area and power. A theory of local government. Glencoe, Ill.: The Free Press.

Zeh, Wolfgang. 1979. Musterfall Gemeinschaftsaufgaben. Erscheinungsformen, Willensbildungsmuster und Ursachen der Politikverflechtung', Der Bürger im Staat Heft 1, 15-19.

Ziebura, Gilbert. 1982. Internationalization of capital, international division of labour and the role of the European Community', Joumal of Common Market Studies 21, 127-40. 